\title{
Protiteroristická politika Evropské unie
}

\author{
Miroslav Mareš
}

Vstup České republiky (ČR) do Evropské unie (EU) se uskutečňuje v období bouřlivých změn globálního bezpečnostního prostředí. Zřejmě nejvýznamnější současnou hrozbou, na kterou musí jak ČR, tak EU reagovat, je terorismus. V posledních letech, zvláště pak po 11. září 2001, se zásadním zpo̊sobem projevil vzestup islámského terorismu, který díky své akceschopnosti a svým cílům představuje kvalitativně novou formu terorismu, což se alespoň částečně promítá i do způsobů jeho potlačování (namísto nástrojů vnitřní bezpečnosti musejí být často využívány vojenské prostředky a operace). Území EU výrazně zasáhly i atentáty Al-Kajdy v Madridu 11. března 2004 (které byly spáchány v době dokončování tohoto textu).

$\mathrm{Na}$ efektivitu a ospravedlnitelnost různých forem boje proti terorismu existují rozdílné názory, přičemž $\mathrm{v}$ posledních letech se objevily poměrně zásadní rozpory mezi některými kontinentálními evropskými státy (zvláště pak mezi Francií a Německem) na straně jedné a Spojenými státy americkými, Velkou Británií a některými postkomunistickými zeměmi (především Polskem) na straně druhé. Konfliktní linie, týkající se ochrany osobních dat a soukromí jednotlivců i dalších lidských práv v souvislosti s bojem proti terorismu, existuje i mezi státními orgány a některými nevládními organizacemi. EU přitom není pouze aktérem protiteroristické politiky, resp. koordinátorem politiky členských států, ale její instituce, zaměstnanci či př́znivci se stávají důležitým motivem teroristické propagandy, a dokonce i selektivním cílem teroristických útoků (naposledy v tomto směru postihla EU dopisní bombová kampan̆ na konci roku 2003, za níž zřejmě stáli italští anarchisté).

\section{Protiteroristická politika v rámci Evropských společenství do prijietí Maastrichtské smlouvy}

Terorismus je fenoménem, který se objevuje v mnoha různých podobách. Mnozí odborníci z akademické sféry i z bezpečnostně-politických institucí usilují o vytvoření univerzální definice, která by postihla všechny formy terorismu, do současnosti však nedospěli k jedno-

Sociální studia. Fakulta sociálních studií Masarykovy univerzity v Brně, 1/2004. S. 21-48. ISSN 1212-265X.

Tento text byl zpracován v rámci grantového projektu GAČR 407/03/D 105 „Politické násilí a terorismus v České republice“. 
značnému výsledku (Strmiska 2001). Častá (a doposud ne zcela úspěšně zvládnutá) je i snaha převést definice do právní polohy (Mareš 2002), a to i v rámci evropské legislativy. Přestože se o pojetí a rozčlenění terorismu vedou spory, je zřejmé, že jako určitá forma vyhroceného násilí tento jev výrazně ohrožuje bezpečnost na různých úrovních (od lokální až po globální). Terorismus se projevuje i v Evropě, resp. v EU, přičemž formy ohrožení a role EU jako aktéra v rámci protiteroristické politiky prošly v posledních desetiletích vývojem, který byl provázán s celkovými změnami charakteru terorismu i evropské integrace.

Terorismus na evropském kontinentě existoval dávno před začátkem poválečného evropského integračního procesu, at' již jeho kořeny budou hledány ve všech formách války proti civilistům od starověku (Carr 2002), či (v návaznosti na etymologické pojetí) v jakobínském teroru za francouzské revoluce anebo v subverzivním anarchistickém terorismu na přelomu devatenáctého a dvacátého století (Bonanate 1997). Dále se mj. projevoval v první polovině dvacátého století v kontextu etnického násilí mezi balkánskými národy (a to i teroristickými akcemi mimo tuto geografickou arénu, jako např. atentátem na jugoslávského krále Alexandra v roce 1934 ve Francii), pouličním fašistickým, nacistickým a komunistickým terorem ve dvacátých a třicátých letech, státním terorem totalitních a autoritativních režimů apod. Mezinárodní spolupráce v boji proti terorismu v první polovině dvacátého století nebyla př́liš intenzivní. Zásada mezinárodního nevměšování se do politicky motivovaných zločinů, za něž byly tehdejší teroristické akce většinou pokládány, se až na několik výjimek projevila např. v nečinnosti Světové komise kriminální policie (Interpolu) v protiteroristických aktivitách (Bresler 1992: 44-53). V roce 1937 byla byla na půdě Společnosti národů podepsána Úmluva o předcházení a potlačování terorismu, která však nikdy nevstoupila v platnost.

Po druhé světové válce byl terorismus v západoevropském prostoru dočasně v útlumu. ${ }^{1}$ V šedesátých letech se však opět výrazněji objevuje, a to v především ve formě etnicko-separatisticky motivovaných útoků v jižním Tyrolsku, v Baskicku a v severním Irsku. Tato varianta terorismu eskalovala v sedmdesátých a osmdesátých letech, kdy k jejím dalším nositelům přibyli např. násilní korsičtí či velšští separatisté (Zariski 1989). Na evropské území však byla přenesena i problematika palestinského separatistického (tehdy ještě převážně nekonfesního a levicově orientovaného) terorismu (Hoffman 2001: 85-96). V šedesátých až osmdesátých let letech začali v západoevropské aréně realizovat své aktivity i další etnicko-separatističtí teroristé (napřr. arménští, jihomolučtí, chorvatští, kurdští, sikhští apod.). Od počátku sedmdesátých let přitom dochází i k vzestupu západoevropského ultralevicového terorismu, který vznikl z části studentského a protestního hnutí let šedesátých, př́ípadně se konstituoval z někdejších opozičních proudů v jihoevropských pravicových diktaturách po jejich pádu. Jeho nejvýznamnějšími představiteli se staly skupiny Rudé brigády (BR) v Itálii, Frakce Rudé armády (RAF), Hnutí 2. července a Revoluční buňky/Rudá Zora v SRN, Přímá akce (AD) ve Francii, Bojující komunistické buňky (CCC) v Belgii, Antifašistické skupiny odporu prvního října (GRAPO) ve Španělsku a Organizace 17. listopadu v Řecku. Především RAF a AD se v polovině osmdesátých letech pokoušely vytvořit i sjednocenou ,antiimperialistickou frontu“ všech „revolučních sil“"v Evropě. ${ }^{2}$ Spíše ojedinělými, avšak velmi brutálními akcemi se projevoval i ultrapravicový terorismus. ${ }^{3}$ Ultralevicoví i někteří ultrapravicoví teroristé spolupracovali s palestinskými a libanonskými skupinami (Langguth 1993: 172). Palestincům a levičákům často pomáhal původem venezuelský terorista Iljič Ramiréz Sanchez, známý 
jako Carlos. Ultralevicovému terorismu poskytovaly podporu i některé země komunistického bloku. V osmdesátých letech se v Evropě objevil ve větší míře i terorismus sponzorovaný některými státy z blízkovýchodní oblasti, především z Libye a Iránu (libyjští agenti byli i pachateli atentátu na americké dopravní letadlo společnosti Pan Am nad skotským městem Lockerbie v roce 1988).

Zmíněný nárůst terorismu v západní Evropě v sedmdesátých letech vyvolal i snahu po zefektivnění boje proti němu na úrovni Evropských společenství (ES). Západoevropská integrace byla na přelomu čtyřicátých a padesátých let zahájena jako hospodářský projekt, který měl pouze nepřímé bezpečnostně-politické atributy, a to $\mathrm{v}$ jiných oblastech než ve vnitřní bezpečnostní, ${ }^{4}$ resp. protiteroristické politice (jednalo se např. o posílení ekonomické stability sociální bezpečnosti a o vzájemnou kontrolu výroby důležitých strategických surovin, především oceli). Otevření hranic a související volný pohyb osob v zemích ES však znamenaly kromě řady pozitivních aspektů i větší volnost pro transnacionální působení kriminálníků a teroristů. „Boom terorismu“ v sedmdesátých letech postavil řadu zemí před nutnost zintenzivnit mezinárodní spolupráci proti tomuto jevu. Na globální úrovni bylo sjednáno několik úmluv na půdě Organizace spojených národů, v západní Evropě byla v tomto směru hlavní arénou (vzhledem ke svým kompetencím) Rada Evropy, kde byla v roce 1977 sjednána Evropská úmluva o potlačování terorismu (Šturma, Nováková, Bílková 2003: 28-46). Základy protiteroristické politiky však byly položeny i v rámci Evropských společenství, kde stály i u zrodu jejich působnosti v oblasti vnitřní bezpečnosti obecně.

Již od počátku sedmdesátých let se zintenzivňovala bilaterální policejní spolupráce členských zemí ES, které byly nespokojeny s př́istupem Interpolu k terorismu. ${ }^{5} \mathrm{Na}$ zasedání Evropské rady v Paříži se ve dnech 9.-10. prosince 1974 diskutovalo o větší spolupráci mezi členskými státy v oblasti vnitra. Hrozba terorismu vedla o rok později (především z iniciativy Velké Británie) k tomu, že během zasedání Evropské rady 1.-2. prosince 1975 v Ř́mě byl odsouhlasen návrh britského ministra zahraničí Jamese Callaghana k vytvoření ministerské pracovní skupiny, která se měla věnovat boji proti terorismu. Byla nazvána TREVI. ${ }^{6}$ Dne 29. června 1976 se pak v Lucemburku sešli ministři vnitra a spravedlnosti členských zemí ES, kteří určili následující okruhy činnosti TREVI:

a) výměna informací o teroristických činech,

b) výměna informací o teroristických plánech a aktivitách a vzájemná podpora $\mathrm{v}$ jednotlivých př́padech,

c) výměna technických informací,

d) výměna policejních zaměstnanců a zlepšení policejního vzdělávání,

e) spolupráce při ochraně civilní letecké dopravy,

f) ochrana jaderných zařízení a transportů a spolupráce v ochraně před katastrofami (Knelangen 2001: 90-91).

Organizačně mělo TREVI třístupňovou strukturu. V čele byli ministři vnitra a spravedlnosti členských zemí (nejvyšší úroveň), kteří se do roku 1985 setkávali jednou, poté dvakrát ročně. Stálý sekretariát neexistoval. Administrativní zabezpečení bylo vykonáváno předsednickým státem, přičemž institut předsednictví byl paralelní s předsednictvím ES. Obsah jednání byl připravován odpovědnými ministerskými úředníky (stř̌ední úroveň), kteří zároveň 
fungovali jako orgán dozoru nad pracovními skupinami (nejnižší úroveň), jež v rámci TREVI vznikly ke konkrétním tématům. V nich se scházeli zástupci ministerstev, policejních a celních úřadů i zpravodajských služeb. Pracovní skupiny TREVI vznikly zpočátku (v roce 1977) pouze dvě, a to TREVI I pro boj s terorismem ${ }^{7}$ a TREVI II pro policejní otázky, vzdělání a vybavení. V roce 1985 přibyla TREVI III pro boj s organizovaným zločinem, v roce 1989 (po celkové reorganizaci TREVI a v celkovém kontextu změny politiky vnitřní bezpečnosti s perspektivou jejího začlenění do připravované Smlouvy o EU) pak TREVI IV pro opatření na hranicích a později i pracovní skupina pro zrrízení Evropské protidrogové jednotky a Europolu (Knelangen 2001: 92).

TREVI nebylo orgánem ES, přestože se na něm podílely jejich členské státy. Byla to čistě mezivládní forma spolupráce, která byla realizována v podmínkách značného utajení. Nebyla nad ní vykonávána př́má parlamentní kontrola ani ze strany Evropského parlamentu, ani ze strany parlamentů národních. Proto byla kritizována Evropským parlamentem i organizacemi zaměřenými na ochranu lidských práv (Fiala, Pitrová 2003: 597). Celkové hodnocení TREVI je rozporuplné. V jednotlivých př́ípadech bylo dosaženo určitých úspěchů, realizace stabilně efektivní politiky však byla problematická. V oblasti protiteroristického boje měly totiž jednotlivé státy rozličné zájmy. Země jako Německo, Francie, Itálie či Velká Británie, které byly konfrontovány s terorismem intenzivněji, se v rámci TREVI snažily angažovat více než státy Beneluxu, jež tak velké problémy neměly. Každý stát byl navíc zainteresován především na informacích o skupinách, které jej bezprostředně ohrožovaly (napřr. Velká Británie na IRA, zatímco Německo, Itálie a Francie na zde působících ultralevicových skupinách) (Knelagen 2001: 97). TREVI sice na jedné straně prokázalo schopnost kooperace členských zemí ES v policejní oblasti, na straně druhé však ještě nepředstavovalo důkladně zakotvený a institucionalizovaný prvek vnitřní bezpečnostní politiky ES. Ta reálně vznikla (včetně nástrojů ES/EU k boji proti terorismu) až díky schengenské spolupráci a Maastrichtské smlouvě a precizována byla v Amsterodamské smlouvě a v průběhu dalšího vývoje EU.

\section{Institucionální a právní rámec protiteroristické politiky Evropské unie}

Boj proti terorismu realizovaný Evropskou unií je nutné analyzovat na více úrovních. Protiteroristická politika se $\mathrm{v}$ rámci ES/EU stala především součástí širší politiky vnitřní a později i vnější bezpečnosti EU, což souviselo i se změnou charakteru terorismu a dalších bezpečnostních hrozeb. Po skončení studené války se postupně utlumily aktivity „tradičního" západoevropského ultralevicového terorismu. Ultrapravicové násilí bylo poměrně intenzivní, ale stalo se spíše záležitostí neformálních rasistických subkultur než rigidně organizovaných skupin. Neustaly však aktivity některých evropských etnicko-regionálních teroristů (především korsických a baskických, nejasná je rovněž situace v severním Irsku). Přinejmenším od poloviny devadesátých let navíc začaly evropskou bezpečnost stále více ohrožovat skupiny militantních islamistů (Delpech 2002: 8-9), které vznikly zpravidla mimo EU. Na území jejích členských států však vytvářely své buňky v přistěhovaleckých komunitách. Postupně se řada původně autonomních regionálních islamistických skupin (např. alžírská GIA) začlenila do volné sítě Al-Kajda, která v prvních letech nového tisíciletí představovala největší teroristickou hrozbu pro západní civilizaci (svoji akceschopnost prokázala především útoky na USA 11. září 2001, je odpovědná i za atentáty v Madridu 
11. března). Boj proti ní se odehrává jak v rámci EU, tak i mimo ni při potlačování terorismu v oblastech, kde se mu dostává podpory a kde má své základny, případně kde pro svoji činnost získává zbraně a finanční zázemí (často díky propojení s organizovaným zločinem). Tento boj se prolíná i s problematikou boje proti proliferaci s ohledem na možnost použití zbraní hromadného ničení teroristy (Müller 2003).

Základním předpokladem pro protiteroristickou politiku je vymezení kompetencí ES/EU v základních smlouvách. V Maastrichtské smlouvě z roku 1992 byla bezpečnostní politika (do níž boj proti terorismu spadá) zapracována především do oblasti druhého (Společná zahraniční a bezpečnostní politika, tj. vnější bezpečnosti) a třetího pilíře (oblast justice a vnitřních věcí, tj. vnitřní bezpečnosti), tedy v oblasti mezivládní spolupráce ${ }^{8}$ (a jednomyslného rozhodování, avšak s možností tzv. užší spolupráce). Kromě toho se již od roku 1985 rozvíjela „konkurenčně“ i spolupráce v rámci tzv. Schengenského systému9 ${ }^{9}$, která byla v Amsterodamské smlouvě (podepsána 1997, vstup v platnost 2001) začleněna do Smluv ES/EU (platí však pouze pro členské státy Schengenských dohod). Amsterodamská smlouva rovněž převedla azylovou politiku a oblast civilní justiční spolupráce do oblasti prvního pilíre EU. V prvním pilíri jsou zpravidla přijímána i opatření v oblasti civilní ochrany, tj. včetně ochrany při teroristických útocích (Pikna 2003: 351-377) a některé otázky související s bezpečností dopravy, financováním terorismu a rozvojovou pomocí v oblastech, kde vznikají pro terorismus předpoklady (Khol 2001: 9). Vytváření prostoru svobody, bezpečnosti a práva dostalo výrazný impulz na zasedání Evropské rady v Tampere 15.-16. října 1999. Směřování k větší spolupráci v této oblasti potvrdila i Smlouva z Nice (podepsána 2001, vstup v platnost 2003), která přinesla mj. zakotvení Eurojustu. Vytvořila i nové možnosti pro rozvoj Společné zahraniční a bezpečnostní politiky EU. Návrh evropské ústavy, jenž nebyl v roce 2003 přijat, přepokládá sloučení všech tří pilířu EU, včetně jednotných právních nástrojů.

Komplexnost protiteroristické politiky znamená, že se do ní v různých oblastech zapojují v podstatě všechny hlavní orgány ES/EU. Základní aspekty směřování EU (včetně možnosti boje proti terorismu) formuluje jako vrcholných orgán současné institucionální struktury Evropská rada. Schvalování základních smluv ES/EU a jejich změn podléhá ratifikačním procesům v evropských i národních orgánech. Velmi důležitým orgánem v oblastech druhého i třetího pilíře je Rada (ministrů zahraničí, resp. ministrů vnitra a spravedlnosti). „Protiteroristické“ kompetence Komise, Evropského parlamentu a Evropského soudního dvora sice $\mathrm{v}$ dílčích aspektech existují, ale jsou zde oproti oblasti prvního pilíre omezeny (Pitrová, Fiala 2003: 169-372).

Ve stávajícím třetím pilíři je konstatováno, že si EU klade za cíl „poskytovat svým občanům v prostoru svobody, bezpečnosti a práva vysokou úroveň ochrany tím, že rozvíjí společný postup členských států v oblasti policejní a justiční spolupráce v trestních věcech a tím, že přechází a potírá rasismus a xenofobii““ (Amsterodamská smlouva, čl. 29).

Smlouva o EU zakotvuje v hlavě VI následující možnosti společného postupu využitelné rovněž v boji proti terorismu:

a) spolupráci policejních orgánů, celních orgánů a jiných kompetentních donucovacích orgánů členských států;

b) využívání možností Europolu a zvláště zřizování společných vyšetřovacích týmů; 
c) užší spolupráci justičních orgánů včetně využívání takových nástrojů, jako jsou Eurojust, evropský zatýkací rozkaz a zjednodušení procesu předávání v trestních věcech mezi členskými státy Unie;

d) použití zvláštních opatření právních a organizačních v boji proti mezinárodnímu terorismu,

e) harmonizaci na úseku předpisů trestního práva;

f) uzavírání mezinárodních dohod spolu s dalšími vnějšími aktivitami Unie (Pikna 2003: 338).

Právními nástroji v oblasti třetího pilíře jsou po přijetí Amstrodamské smlouvy: ${ }^{10}$

a) rámcová rozhodnutí (přijímá je Rada za účelem sbližování právních a správních předpisů členských států Unie; jsou závazná co do výsledku, kterého má být dosaženo, přičemž volba forem a prostředků se ponechává národním orgánům členských států; nemají př́mý účinek v členských zemích),

b) rozhodnutí (jsou přijímána Radou za jakýmkoliv jiným účelem, který je v souladu s cíli třetího pilíře s výjimkou sbližování právních a správních předpisů členských států; jsou pro členské státy závazná, nemají ale př́mý účinek),

c) společné postoje (zaujímá je Rada a vymezuje př́istup Unie k určité otázce, právní status není zcela zřejmý),

d) úmluvy (Rada je oprávněna vypracovávat úmluvy, které pak doporučí k přijetí v souladu $\mathrm{s}$ jejich př́islušnými ústavně právními předpisy).

I ve třetím pilíŕi hraje tedy nejvýznamnější roli Rada. Po madridských atentátech byla při Radě ministrů spravedlnosti a vnitra zřízena funkce protiteroristického koordinátora (stal se jím nizozemský politik Gijs de Vries). Jeho pravomoci a působnost však spočívají v podstatě pouze v usnadňování kooperace členských zemí a evropských orgánů.

Ze specializovaných institucí EU, které přispívají k boji proti terorismu, je pro realizaci spolupráce policejních složek důležitý Evropský policejní úřad (Europol). O založení Eurpolu bylo rozhodnuto Maastrichtskou smlouvou. Omezenou činnost zahájil 3. ledna 1994 na prozatímním základě jako Protidrogová jednotka Europolu. Kompetence tohoto útvaru byly postupně rozšiřovány. V roce 1995 byla podepsána Úmluva o Europolu, která vstoupila v platnost 1. ř́ína 1998. Svoji činnost zahájil Europol v plném rozsahu 1. května 1999. Sídlem Europolu je Haag. Orgány Eurpolu jsou správní rada (tvořená zástupci členských států), ředitel (jmenovaný na období čtyř let s možností jednoho obnovení funkčního období), kontrolor financí a finanční výbor. Europol rovněž disponuje styčnými důstojníky ze všech členských zemí, kteří zastupují orgány př́islušné pro mezinárodní spolupráci (policii, celní správu, četnictvo, finanční policii, cizineckou policii apod.). Každá národní jednotka přiděluje k Europolu alespoň dva styčné důstojníky. Členský stát je povinen zř́idit nebo určit národní jednotku Europolu pověřenou prováděním určitých úkolů..$^{11}$ Národní jednotka je styčným subjektem mezi Europolem a př́slušnými orgány členských států (Pikna 2003: 236). Europol uzavírá i bilaterální dohody s národními státy, má uzavřenu i dohodu s Interpolem.

Cílem Europolu je v rámci spolupráce členských států podle čl. 29 Smlouvy o EU zlepšit prostřednictvím opatření uvedených v Úmluvě o Europolu účinnost a spolupráci při předcházení terorismu, předcházení nedovolenému obchodu s drogami a jiným závažným formám mezinárodní trestné činnosti a bojovat proti nim tam, kde jsou konkrétní známky, že jde o or- 
ganizovanou kriminální strukturu a dva nebo více členských států je dotčeno př́íslušnými formami trestné činnosti takovým způsobem, že to vzhledem k rozsahu, významu a k následkům deliktů vyžaduje společný postup členských států (Pikna 2003: 231). ${ }^{12}$

Podle Filipa Křepelky neusilovali zakladatelé Europolu o vytvoření samostatné policejní jednotky, která by dokázala vykonávat a skutečně vykonávala všechny policejní činnosti související s vymezenou kriminalitou sama. Europol je dle něj spíše policejní ústřednou než policií v pravém slova smyslu. Zabezpečuje výměnu informací mezi členskými státy a zjištěné analyzuje a eviduje (Křepelka 2002: 218). Podle Bohumila Pikny však Amstrodamská smlouva zásadním způsobem mění celkové pojetí práce Europolu v tom smyslu, že doplňuje jeho poslání o posílení atributu operativního šetření a policejního vyšetřování, a to hlavně za využití možností společných týmů (Pikna 2003: 231). Europol ale rozhodně není ekvivalentem amerického Federálního úruadu vyšetřování (FBI) (Křepelka 2002: 220-221, Marotta 2001: 18), i když někteří příznivci evropské integrace by jej chtěli postupně do této podoby přetvořit.

Z výkonu své činnosti je Europol odpovědný Radě EU (Rada ministrů spravedlnosti a vnitra), která má na starosti hlavní kontrolu a řízení funkcí Europolu. Rada také schvaluje rozpočet a jmenuje ředitele Europolu i s jeho zástupci. Za zvláštní činnost dohledu lze považovat každoroční povinnost předkládat zprávu o činnosti Europolu Evropskému parlamentu (Pikna 2003: 226-227).

Podle Úmluvy má Europol v rámci plnění svých cílů přednostně za úkol:

a) usnadňovat výměnu zvláště operativních informací mezi svými členskými státy;

b) získávat, shromažd'ovat a analyzovat informace a poznatky;

c) bezodkladně oznamovat prostřednictvím svých národních jednotek příslušným orgánům členských států informace, které se jich týkají, a všechny zjištěné souvislosti mezi trestnými činy;

d) napomáhat vyšetřování v členských státech předáváním důležitých informací národním jednotkám;

e) udržovat počítačový systém výměny informací, který obsahuje údaje v souladu s Úmluvou o Europolu.

K tomu, aby se prostřednictvím národních jednotek Europolu (viz níže) v rámci stanovených cílů zlepšila spolupráce a výkonnost příslušných orgánů v členských státech, plní navíc Europol tyto další úkoly:

f) prohlubuje odborné znalosti vyšetřovacích postupů používaných příslušnými orgány v členských státech a nabízí při realizaci vyšetřování odborné konzultace;

g) předává strategické poznatky, aby se usnadnilo a podpořilo účinné a racionální používání prostředků dostupných na vnitrostátní úrovni pro operativní úkoly;

h) připravuje př́islušné souhrnné zprávy.

Kromě toho může Europol v rámci svých cílů podporovat členské státy konzultacemi a výzkumem v oblastech dalšího vzdělávání pracovníků př́slušných orgánů, jejich organizování a materiální vybavení a na úseku týkajícím se metod trestní prevence, kriminalistických a kriminalisticko-vědeckých metod včetně metod vyšetřovacích (Pikna 2003: 233). Další oprávnění získal Europol po 11. září 2001 v souvislosti s bojem proti terorismu. 
Europol vytvořil pro realizaci své činnosti v oblasti shromažd'ování dat (tj. pouze pro činy, pro které je příslušný) počítačový systém Europolu (The Europol Computer System TECS), který se skládá ze tř́i základních složek, a sice:

1) informačního systému (Europol Information System - EIS),

2) systému analýz (Analytical Work Files - AWF),

3) indexového systému (IIS - Interim Information Systém - IIS) (Pikna 2003: 233).

Základní atributy těchto systémů jsou zachyceny v následující tabulce:

\section{Tabulka 1}

Architektura počítačového systému Europolu

\begin{tabular}{|c|c|c|c|}
\hline & informační systém & systém analýz & indexový systém \\
\hline obsah & $\begin{array}{l}\text { Údaje o osobách: } \\
\text { - které byly odsouzeny za } \\
\text { trestný čin } \\
\text { - které jsou podežrelé ze } \\
\text { spáchání trestného činu } \\
\text { - u kterých závažné } \\
\text { důvody ospravedlňují } \\
\text { domněnku, že spáchají } \\
\text { trestný čin }\end{array}$ & $\begin{array}{l}\text { Údaje za účelem analýz } \\
\text { týkající se: } \\
\text { - osob z informačního } \\
\text { systému } \\
\text { - možných svědků } \\
\text { - obětí nebo možných } \\
\text { obětí } \\
\text { - kontaktních nebo } \\
\text { doprovodných osob } \\
\text { - možných informátorù }\end{array}$ & $\begin{array}{l}\text { záznamy } \\
\text { o analyzovaných údajích }\end{array}$ \\
\hline druhy údajů & $\begin{array}{l}\text { - údaje o identitě } \\
\text { - údaje o činu } \\
\text { - údaje o podežrení } \\
\text { z přílušnosti ke kriminální } \\
\text { organizaci }\end{array}$ & $\begin{array}{l}\text { podle článku } 6 \text { Úmluvy; } \\
\text { v zásadě: zprostředkování } \\
\text { prostřednictvím národních } \\
\text { jednotek podle národního } \\
\text { práva s omezením užití }\end{array}$ & $\begin{array}{l}\text { zpráva, zda je informace } \\
\text { uložena v analytických } \\
\text { údajích, avšak bez } \\
\text { odkazu na obsah údajů }\end{array}$ \\
\hline $\begin{array}{l}\text { zisk } \\
\text { prostřednictvím }\end{array}$ & $\begin{array}{l}\text { národních jednotek } \\
\text { podle národního práva, } \\
\text { Europolem u údajů od } \\
\text { třetích osob a údajů } \\
\text { získaných analytickou } \\
\text { činností }\end{array}$ & analytiků Europolu & Europolu \\
\hline $\begin{array}{l}\text { přístup } \\
\text { prostřednictvím }\end{array}$ & $\begin{array}{l}\text { národních jednotek } \\
\text { podle opatření národního } \\
\text { práva, styčnými } \\
\text { důstojníky, řediteli, } \\
\text { zmocněnými zaměstnanci } \\
\text { Europolu }\end{array}$ & analytiků Europolu & $\begin{array}{l}\text { ředitele, zaměstnanců } \\
\text { Europolu, styčnými } \\
\text { důstojníky }\end{array}$ \\
\hline $\begin{array}{l}\text { odpovědnost } \\
\text { za ochranu dat }\end{array}$ & $\begin{array}{l}\text { zprostředkující členský } \\
\text { stát, Europol omezen } \\
\text { vlastními předpisy } \\
\text { o zpracování údajo } \\
\text { a zpracování údajů od } \\
\text { tretích osob }\end{array}$ & Europol & Europol \\
\hline
\end{tabular}

Pramen: Knelangen 2001: 241.

Europol vytváří pro zabezpečení údajů v TECS společný konotrolní orgán (Joint Supervisity Body), povinností každého členského státu je navíc určit nezávislý kontrolní orgán, jenž dohlíží na přípustnost vkládání a vyhledávání osobních údajů Europolem, a zkoumat, zda 
tím nejsou porušována práva dotčených osob (Pikna 2003: 234-235). Shromažd'ování údajů v databázích Europolu a s tím související údajně nedostatečná kontrola (především parlamentní) je již od počátku zakotvení Europolu do struktury EU častým terčem kritiky některých odborníků, nevládních organizací na ochranu lidských práv i určitých politických proudů v Evropě. ${ }^{13}$

Policejní a zpravodajská spolupráce v boji proti terorismu, především př́i předávání a výměně informací a operativní spolupráci, je realizována i prostřednictvím Policejní pracovní skupiny k terorismu (Police Working Group on Terrorism - PWGT). Její podřazení do struktury EU však může být sporné. Jedná se o orgán, který vznikl za souhlasu ministrů vnitra nebo ministrů spravedlnosti. Nejedná ale jako koordinační orgán v rámci struktury EU s výjimkou situace, kdy o to některá z členských zemí ${ }^{14}$ ve specifických př́padech požádá. Výměna, předávání a využití informací se dějí v souladu s legislativou platnou pro policejní složky členských zemí (používán je i vlastní komunikační systém pro výměnu informací). Pracovní setkání se konají dvakrát do roka. PWGT se skládá ze zástupců evropských policejních složek nesoucích v rámci svých zemí celostátní odpovědnost za problematiku:

a) boje proti (mezinárodnímu) terorismu,

b) boje proti násilí s politickým podtextem,

c) ochranné služby,

d) vyšetřování a analýzu explozí,

e) vyšetřování válečných zločinů pod záštitou OSN v místech konfliktů,

f) zajištění speciálních operací,

g) někdy plní též funkci zpravodajské služby (Irsko a skandinávské země).

Dalším orgánem, který na úrovni EU přispívá k boji proti terorismu, je Evropská jednotka pro soudní spolupráci (Eurojust). Její existence byla zakotvena Niceskou smlouvou. Eurojust jako orgán EU byl založen rozhodnutím Rady EU o zřízení Evropské jednotky pro soudní spolupráci za účelem posílení boje proti závažné trestné činnosti z 28. února 2002, které nabylo účinnosti 6. března téhož roku. ${ }^{15}$ Rada má podporovat spolupráci prostřednictvím Eurojustu tím, že:

a) umožňuje Eurojustu přispívat k dobré koordinaci mezi orgány členských států Unie činných v trestním řízení;

b) podporuje pomoc poskytovanou Eurojustem při vyšetřování závažné přeshraniční trestné činnosti, zejména pak v případech organizované trestné činnosti, zvláště s ohledem na rozbory provedené Europolem;

c) usnadňuje úzkou spolupráci Eurojustu s Evropskou justiční sítí zejména proto, aby byl usnadněn výkon dožádání a žádosti o vydání (Pikna 2003: 266-269).

Do boje proti terorismu se mohou zapojit i tzv. společné vyšetřovací týmy ${ }^{16}$ (Pikna 255-266). Dalším specializovaným orgánem ES v oblasti vnitřní bezpečnosti, který se může zapojit do protiteristické politiky, je Evropský úřad pro potírání podvodných jednání (Organisation de la Lutte Antifraud - OLAF). Zajišt’uje spolupráci mezi členskými zájmy a Komisí za účelem ochrany finančních zájmů společenství. Byl zřízen rozhodnutím Evropské komise s účinností od 1. června 1999. Má nezávislý status a jeho hlavní úlohou je provádět správní vyšetřování (Pikna 2003: 281-284). Do interakce s problematikou terorismu se může dostat např. při pátrání po tom, zda finanční zdroje ES neslouží v ko- 
nečném důsledku k financování terorismu. ${ }^{17}$ Výuka problematiky spojené s terorismem je i záležitostí Evropské policejní akademie (CEPOL). Terorismem se mohou v souvislosti s jeho financováním zabývat i další orgány EU zaměřené na tuto oblast, v řadě aspektů je problematika boje proti němu propojena i s potíráním organizovaného zločinu a korupce, ochrany lidských práv a s bojem proti rasismu a xenofobii apod., což přináší i angažovanost řady dalších institucí EU v oblasti třetího i prvního pilíře, zapojených do těchto sektorových politik.

V boji proti terorismu by se mohly angažovat i orgány, o jejichž existenci se pouze uvažuje. Tzv. Corpus Iuris je zatím nezávazný soubor norem trestního práva určený k minimální ochraně zájmů ES vypracovaný členy Asociace evropských právníků. Předpokládá např. zrrízení Úřadu evropského veřejného žalobce (Pikna 2003: 291-295). Diskutována byla i možnost vzniku Evropské hraniční stráže (European border guard service), což bylo např. neúspěšně navrhováno některými delegáty na zasedání Konventu EU. ${ }^{18}$ Odmítavé stanovisko bylo odůvodněno mj. s poukazem na jazykové problémy (plenární setkání Konventu 6.-7. 6. 2002). Zatím pouze ve stadiu vágních úvah jsou projekty na zrrízení jednotné evropské zpravodajské služby, tzv. European Intelligence Agency ${ }^{19}$ (v poslední době se o ní intenzivně uvažovalo především po madridských atentátech v březnu 2004, nakonec však bylo dohodnuto pouze zintezivnění výměny informací a zesílení spolupráce mezi zpravodajskými službami pěti hlavních zemí EU) či evropské protiteroristické zásahové jednotky.

V oblasti druhého pilíře EU, tj. společné zahraniční a bezpečnostní politiky (SZBP), jsou po Amsterodamské smlouvě ${ }^{20}$ právními nástroji:

a) zásady a obecné směry SZBP, které přijímá Evropská rada (na jejich základě pak Rada EU jednomyslně přijímá potřebná rozhodnutí pro provádění SZBP);

b) společné strategie, jež Unie uskutečňuje v oblastech, kde mají členské státy společné zájmy (rozhoduje o nich Evropská rada, může se tak dít na doporučení Rady EU, která je pak realizuje zejména ve formě přijímání společných akcí a zaujímání společných postojů;

c) společné postoje, které mají vymezovat přístup Unie ke konkrétní záležitosti geografické nebo tematické povahy s tím, že členské státy zajistí, aby jejich národní politiky byly v souladu s těmito společnými postoji (tento právní akt vydávaný Radou je pro členské státy závazný);

d) společné akce zaměřené na řešení specifických situací, při nichž se operační akce Unie považuje za žádoucí (přijímá je Rada a jsou pro členské státy závazné) (Pikna 2003: 292).

Stát, který nesouhlasí s konkrétní aktivitou a současně ji nechce zablokovat, má možnost tzv. konstruktivní absence. Nemusí hlasovat, ale v př́ípadě, že je rozhodnutí přijato, akceptuje fakt, že rozhodnutí zavazuje EU jako celek (Fiala, Pitrová 2003: 572).

SZBP prošla v posledních letech bouřlivým vývojem. Intenzivně začaly být budovány vojenské kapacity EU v kontextu společné bezpečnostní a obranné politiky, a to i v souvislosti s utlumením činnosti Západoevropské unie ve prospěch Evropské unie. ${ }^{21}$ Do struktury SZBP je zapojena řada obecně zaměřených i specializovaných institucí EU, mj. Evropská rada, tzv. Trojka, vysoký zmocněnec pro SZBP, Jednotka politického plánování a včasného varování, zvláštní vyslanci, Rada EU, COREPER, evropští korespondenti, pracovní skupiny SZBP, politický a bezpečnostní 
výbor, vojenský výbor, vojenský štáb EU a dále i Komise, členské státy, skupina poradců SZBP a Evropský parlament (který projednává rozvoj SZBP, informuje předsedající stát o svých postojích, dává doporučení Radě, může ji interpelovat) (Fiala, Pitrová 2003: 577).

Přestože však má EU vybudován právní a institucionální rámec SZBP i SOBP, je praktická realizace s ohledem na rozdílné národní zájmy členských států mnohdy velmi problematická, což ukázaly mj. rozdílné postoje k útoku proti Iráku v roce 2003. Otázkou zůstává i vzájemný vztah EU a NATO. Řada členských států EU a NATO považuje za hlavní pilír své bezpečnosti NATO (což platí i pro nové členské země ze střední a východní Evropy) a transatlantické spojenectví. SZBP EU tak mohou tyto státy vnímat pouze jako jistý „doplněk“ prioritní podpory NATO (Khol 2003a). V posledních letech se přitom zřetelně projevuje duplicita některých činností a cílů v obou organizacích, což vyvolává snahy po jejich sjednocení, a tím i zefektivnění jejich působení (na druhé straně ale neutrální státy EU své případné plné zapojení do „evropského pilíře NATO“ odmítají). Paralelnost některých soudobých procesů v rámci EU a v NATO je zachycena v následující tabulce:

\section{Tabulka 2}

Paralelnost činnosti NATO a EU

\begin{tabular}{|l|l|}
\hline NATO & EU \\
\hline přizpưsobování aliančních struktur & vytváření vojenské akceschopnosti \\
\hline posílení evropského pilǐre, zlepšení schopností & $\begin{array}{l}\text { krizový management s vojenskými prostredky, } \\
\text { Uzavření mezer v akceschopnosti }\end{array}$ \\
\hline reforma struktury ozbrojených sil & cil „European Headline Goal“ \\
\hline $\begin{array}{l}\text { rozhodnuto o výstavbě nových velitelských struktur } \\
\text { (ve výstavbě) }\end{array}$ & $\begin{array}{l}\text { stanoveny opce vedení, pracuje projektová } \\
\text { skupina pro strategické „OHQ“ }\end{array}$ \\
\hline mobilní „Joint“ HQ ve výstavně „CJTF HQ“ & přislíbeny mobilní „Force Headquarters“ \\
\hline do centra zájmu stavěny „NATO Response Force“ & $\begin{array}{l}\text { vytvářeny oddíly pro rychlé zásahy (část „European } \\
\text { Headline Goal“) }\end{array}$ \\
\hline
\end{tabular}

Pramen: Olshausen 2004: 56.

Ideové spory mezi USA a jejich blízkými evropskými spojenci a dalšími státy EU (resp. mezi jednoznačně proamerickými silami v Evropě a více „europeistickými““ silami) se promítly i do sporů o prŕípustnost ,,preventivních zásahů“ proti terorismu ve smyslu vojenských operací proti státům, které podporují terorismus bez příslušného souhlasu a zmocnění Radou bezpečnosti OSN (Kamp 2004).

\section{Protiteroristická politika EU po 11. zárí 2001}

Výše naznačené spory a problémy mohou limitovat i výsledky protiteroristické politiky EU. Ta přitom po 11. záŕí 2001 podnikla v rámci boje proti terorismu řadu poměrně zásadních opatření, v nichž se prolnula problematika vnitřní i vnější bezpečnosti, třebaže už předtím byla na tomto poli aktivní. ${ }^{22}$ Dne 20. zárí 2001 bylo v Bruselu přijato Společné euro-americké ministerské prohlášení o boji proti terorismu. Na svém mimořádném zasedání 21. září 2001 Evropská rada schválila dokument Usnesení a akční plán boje proti terorismu. Vyjádřila v něm solidaritu se Spojenými státy americkými a boj proti terorismu označila „více než kdy jindy“ za prioritní cíl EU (zároveň kategoricky odmítla klást rovnítko mezi fanatické teroristy a arabský a muslimský svět). Deklarovala připravenost ke spolupráci s USA na potrestání 
pachatelů, přičemž uvedla, že Rezoluce Rady bezpečnosti 1368 učinila odvetu Spojených států legitimní. Vyzvala k vytvoření celosvětové koalice proti terorismu vedené Spojenými národy a zahrnující vedle USA a EU kandidátské země, Ruskou federaci a „,naše arabské a muslimské partnery a každou další zemi připravenou bránit námi sdílené hodnoty“ (usnesení a akční plán mimořádného zasedání Evropské rady z 21. záŕí 2001). Hlavními oblastmi působení EU proti terorismu se na základě akčního plánu staly:

a) posílení policejní a justiční spolupráce (mj. zavedení evropského zatykače a přijetí jednotné definice terorismu, vypracování společného seznamu teroristických organizací, posílení Europolu v boji proti terorismu a ustavení speciálního týmu v jeho práci, který bude úzce spolupracovat se svými protějšky v USA),

b) vytváření mezinárodních právních nástrojů (rychlá implementace všech existujících smluv o boji proti terorismu a podpora vzniku obecné smlouvy OSN proti mezinárodnímu terorismu),

c) ukončení financování terorismu,

d) posílení letové bezpečnosti,

e) koordinace světových akcí EU (zahrnutí boje proti terorismu do SZBP).

Akční plán rovněž předpokládal větší roli EU při předcházení regionálních konfliktů a jejich stabilizaci a vytvoření celosvětového systému bezpečnosti. Vyzval i k opatřením k zabránění negativních ekonomických důsledků 11. září 2001 (usnesení a akční plán mimořádného zasedání Evropské rady z 21. záŕí 2001).

Evropská rada upřesnila některé aspekty protiteroristické politiky EU na zasedání ve dnech 19.-21. ř́jina 2001 v Gentu (jednalo se především o detaily evropského zatykače, těsnější součinnost operativních protiteroristických služeb, opatření proti financování terorismu a o bezpečnost letové dopravy a dále např. o ustavení evropského koordinátora pro opatření na poli civilní ochrany).

EU realizovala již zmíněné posílení, resp. vytvoření nových institucí k boji proti terorismu, at' se již jedná o zrrízení speciální protiteroristické jednotky Europolu, vznik Eurojustu, či společných vyšetrovacích týmů. Počátkem prosince 2001 bylo dosaženo i politické dohody o evropském zatykači, přičemž jeho podrobnější úpravu přineslo Rámcové rozhodnutí Rady z 13. června 2002 o evropském zatykači a procesu předávání mezi členskými státy. Evropský zatykač, na jehož základě může jeden členský stát přistoupit k zatčení a k předání osoby hledané za účelem trestního stíhání nebo výkonu trestu jiným členským státem, nahrazuje systém „tradičních“ extradičních řízení. Zatykač se uplatňuje na trestné činy, které jsou v dokumentu explicitně vymezeny a mezi nimiž figuruje i terorismus. Odpadá požadavek oboustranné trestnosti a výrazně se omezují důvody, pro něž státy mohou, resp. musejí výkon zatykače odmítnout (Šturma, Nováková, Bílková 2003: 48).

Zásadní trojici dokumenti̊, prosazujících mj. v rámci EU závěry rezoluce Rady bezpečnosti OSN 1373 (2001), přijala Rada 27. prosince 2001. Společný postoj Rady z 27. prosince 2001 o boji proti terorismu (2001/930/SZBP) se týká především otázek financování terorismu, přičemž toto jednání v rámci EU a pro její občany kriminalizuje a prostředky takto určené se mají na základě tohoto postoje zmrazit. Teroristům je rovněž bráněno v zneužívání institutu uprchlíka a azylanta (Společný postoj Rady z 27. prosince 2001 o boji proti terorismu). Nař́zení Rady 
ES č. 2580/2001 o zvláštních restriktivních opatřeních namířených proti určitým osobám a subjektům s cílem bojovat proti terorismu upravuje zmrazení peněz, jiných finančních prostředků a ekonomických zdrojů osob a skupin zapojených do teroristických aktivit v EU (Nařízení Rady ES č. 2580/2001 o zvláštních restriktivních opatřeních namířených proti určitým osobám a subjektům s cílem bojovat proti terorismu). Společný postoj Rady o použití zvláštních opatření v boji proti terorismu z 27. prosince 2001 (2001/931/SZBP) definuje za účelem zmrazení peněz a jiného finančního majetku a ekonomických zdrojů „osoby, skupiny a subjekty zapojené do teroristických činů“, „teroristický čin“ a „teroristickou skupinu“ (výše uvedené skupiny a osoby jsou vedeny v seznamu, který je pravidelně aktualizován). Zjednodušeně se hovoří i o tzv. „evropské definici terorismu“ (která kombinuje tři prvky: způsob provedení činu, charakter činu a záměry pachatele, viz Šturma, Nováková, Bílková 2003: 49), i když zde terorismus jako pojem prímo definován není a právní status společného postoje je co do závaznosti sporný. Na druhé straně je fakticky závaznost vyjádřena ve výše zmíněném nařízení Rady ES č. 2580/2001 tím, že tento komunitární právní předpis stanoví, že pro účely tohoto nařízení platí definice teroristického činu uvedená v článku 1 odst. 3 společného postoje č. 2001/931/SZBP (Pikna 2002: 226).

Tuto definici navíc přebralo Rámcové rozhodnutí Rady EU o boji proti terorismu z 13. června 2002, což je již - co do výsledku - právně závazný akt třetího pilíře. Toto rámcové rozhodnutí stanoví, že „každý členský stát EU přijme opatření nezbytná k tomu, aby jeho vnitrostátní právo považovalo za teroristický čin určitá (v rozhodnutí vymezená) jednání, která na základě své povahy nebo souvislostí mohou vážně poškodit některou zemi nebo mezinárodní organizaci, pokud jsou spáchána s cílem:

1) vážně zastrašit obyvatele; nebo

2) neoprávněně nutit některou vládu nebo některou mezinárodní organizaci k nějakému jednání nebo upuštění od nějakého jednání;

3) vážně destabilizovat nebo rozvrátit základní politické, ústavní, ekonomické nebo společenské struktury některé země nebo některé mezinárodní organizace:

a) útoky na život nějaké osoby, které mohou způsobit smrt;

b) útoky na fyzickou integritu nějaké osoby;

c) únosy nebo braní rukojmí;

d) způsobení rozsáhlého zničení vládního nebo veřejného zařizení, dopravního systému, zařízení infrastruktury včetně informačního systému, pevné plošiny umístěné na kontinentálním šelfu, veřejného místa nebo soukromého majetku, které pravděpodobně ohrozí život nebo povede ke značné hospodářské ztrátě;

e) zmocnění se letadel, lodí nebo jiných dopravních prostředků osobní nebo nákladní dopravy;

f) výroba, držení, opatřování, doprava, dodávka nebo používání zbraní, výbušnin nebo jaderných, biologických nebo chemických zbraní, jakož i výzkum a vývoj biologických a chemických zbraní;

g) vypuštění nebezpečných látek nebo způsobení požárů, výbuchů nebo záplav, v jejichž důsledku dojde k ohrožení lidského života;

h) narušení nebo přerušení dodávky vody, elektřiny nebo jiného základního přírodního zdroje, v jejichž důsledku dojde k ohrožení lidského života;

i) hrozba spácháním kteréhokoliv z činů uvedených pod písmeny a) až h).“ 
Pro účely tohoto rámcového rozhodnutí se teroristickou skupinou rozumí strukturovaná skupina více než dvou osob vytvořená na určitou dobu a jednající ve shodě za účelem spáchání teroristických činů. Strukturovanou skupinou se rozumí skupina, která není vytvořena náhodně pro bezprostřední spáchání nějakého teroristického činu a která nemusí mít formálně vymezené úlohy pro své členy, stálé členstvo ani vytvořenou strukturu.

Rámcové rozhodnutí obsahuje i další ustanovení, jež se týkají trestných činů souvisejících s terorismem, trestnosti účastenství, sankcí, extradice, odpovědnosti právnických osob (Pikna 2003: 340-341) i ochrany a pomoci obětem. Již v jeho preambuli se uvádí, že toto rámcové rozhodnutí respektuje základní práva garantovaná Evropskou úmluvou na ochranu lidských práv a svobod a unijní zakotvení lidských práv (Rámcové rozhodnutí Rady z 13. června 2002 o boji proti terorismu).

Evropská unie v rámci boje proti terorismu realizovala i řadu vlastních diplomatických aktivit, včetně různých forem bilaterální spolupráce (mj. se Spojenými státy americkými např. formou smlouvy mezi USA a Europolem), rozvojové pomoci Afghánistánu, obchodních smluv s Pákistánem a Iránem, podpory blízkovýchodního mírového procesu (přestože aktivity EU jsou v této oblasti často kritizovány za př́lišné ústupky vedení Jásira Arafata) apod.

Rada se rovněž 15 . dubna 2002 rozhodla přijmout soubor opatření k zamezení proliferace zbraní hromadného ničení a jejich nosičů, aby eliminovala možnost jejich získání teroristy. Tím navázala na své předchozí aktivity v politice proti proliferaci (Tůma 2002: 58-73). Terorismus (především ten, jenž je propojený s náboženským fanatismem) a proliferace zbraní hromadného ničení jsou uvedeny jako klíčové hrozby i v bezpečnostní strategii EU Bezpečná Evropa v lepším světě, která byla navržena vysokým zmocněncem EU pro SZBP Javierem Solanou v Soluni v červnu 2003 a schválena v Bruselu v prosinci 2003 (nejděsivějším scénářem je pak podle této strategie obstarání zbraní hromadného ničení některou teroristickou skupinou).

Český politolog Radek Khol uvádí: „Strategie respektuje specifický evropský prrístup ke zvládání krizí, prevenci konfliktů i historickou zkušenost evropské integrace. Tři hlavní pilíře EBS jsou formulovány způsobem, který by měl získat silnou podporu mezi evropskou veřejností, a představují promyšlenou alternativu silovému př́stupu americké supervelmoci“" (Khol 2003b: 7). Jedná se o:

1) rozšíření zóny bezpečnosti kolem Evropy;

2) účinný multilateralismus jako základ stabilního mezinárodního systému;

3) boj proti terorismu, proliferaci zbraní hromadného ničení a organizovanému zločinu.

Návrh strategie však obsahoval podle německého bezpečnostního experta Karl Heinze Kampa i odkazy na skutečnost, že se EU nezříká preventivního užití vojenského moci (Kamp 2004: 8). V tomto směru by byla politika EU blízká politice USA, realita ovšem je a žrejmě i bude jiná. Přestože EU má značné bezpečnostně-politické ambice a v situaci po 11. září 2001 se dokázala shodnout na řadě právních kroků, shoda na konkrétní důležité reálné akci (zvláště pak vojenské) je problematická. Např. po 11. záŕí se podle Radka Khola projevila skutečnost, že národní reflexy v oblasti bezpečnosti a obrany stále zůstávají prioritní. Unijní mechanismy se projevily v prvních týdnech a měsících až jako druhotné. Pokud se Evropané angažovali v multilaterální spolupráci, pak měli spíše tendenci koordinovat svou konkrétní podporu mezinárodní 
koalici proti terorismu pod vedením USA v rámci úzké skupiny velmocí (Khol 2002: 21). Irácká krize v roce 2003 pak odhalila různé rozpory týkající se bezpečnostní politiky a boje proti ,darebáckým státům“ jak uvnitř EU (a to mezi státy i mezi vnitrostátními i transnacionálními politickými proudy), tak i mezi některými evropskými státy (Francií, Německem) a USA (v podstatě se tedy nejednalo o spor USA versus EU, protože EU nebyla jednotná). Efektivní realizace větších akcí „out of area“ (resp. plnění petersberských úkolů) vyžaduje i větší akceschopnost (napřr. v oblasti přepravních kapacit) a technologickou vyspělost evropských armád.

\section{Kritika protiteroristické politiky EU}

Politika EU v rámci boje proti terorismu je v řadě oblastí bouřlivě diskutována. Ne všechny subjekty v EU i mimo ni ji akceptují bez výhrad. Kritika přichází z různých stran a je obsahově značně rozrůzněná (často i kontradiktorní). Obecně lze vymezit následující základní argumenty a jejich nositele (aktéři kritiky jsou přitom vymezeni velmi volně; v realitě je existence stabilních konfliktních linií a jednoznačně profilovaných aktérů často problematicky stanovitelná):

1) kritika (zmiňovaná $v$ předchozí kapitole) údajné neschopnosti EU realizovat vlastní ambiciózní bezpečnostní politiku, a to především ve vojenské oblasti. Na jednu stranu vychází od sil, jež ve vlastní bezpečnostní politice preferují vazbu na NATO a USA a na některé atributy evropské politiky nahlížejí jako na kontraproduktivní tříštění sil (na tuto kritiku pak zpravidla navazuje odsouzení malé ochoty EU k preventivním akcím proti terorismu, jako v př́padě Iráku). Na druhou stranu mohou současnou nedokonalou situaci bezpečnostních struktur kritizovat i „europeistické“ síly, které usilují o její výrazné posílení bez vazby na USA. Jistou ,subdimenzí“ euroamerického sporu je i střet o oprávněnost amerických bezpečnostních opatření ve válce proti terorismu, jenž je do určité míry provázán s druhou následující oblastí kritiky;

2) kritika př́lišného nárůstu moci EU, členských států a jejich bezpečnostních složek v souvislosti s bojem proti terorismu, které údajně prŕliš narušují sféru lidského soukromí (z tohoto pohledu kritizují EU a její opatření různé nevládní organizace a další subjekty z oblasti lidských práv, obdobně argumentují i euroskeptické organizace, kterým vadí nárůst kompetencí EU v citlivé oblasti vnitřní bezpečnosti, paradoxně pak některé „europeistické“ proudy kritizují tato opatření jako ústupek politice USA);

3) kritika př́lišné tolerance $\mathrm{k}$ teroristům, zvláště pak $\mathrm{k}$ palestinským a islamistickým (resp. k palestinským orgánům, které je podporují), která se projevuje mj. nezařazením některých organizací na „teroristickou listinu“ EU či financováním některých sporných projektů na Blízkém východě, jež údajně ve svých konsekvencích slouží k podpoře terorismu (zde jsou hlavními nositeli kritiky politické proudy, které se obecně profilují jako proizralelské a proamerické);

4) kritika toho, že některé skupiny a proudy, které jsou v dokumentech EU klasifikovány jako teroristické, takové nejsou, př́ípadně že jsou v těchto dokumentech do kategorie terorismu řazeny zcela nesouměřitelné subjekty (jako např. Al-Kajda a radikální ochránci zvířat). Tuto kritiku hlásají zpravidla organizace, jež jsou na seznam zařazeny, anebo jejich spojenci, př́ípadně i ,lidskoprávní“ organizace);

5) kritika koncepce, typologie a terminologie terorismu v dokumentech EU, vycházející $\mathrm{z}$ akademické sféry. 
Pokud bude pozornost zaměřena na podrobnější odůvodnění některých doposud neanalyzovaných bodů kritiky, lze konstatovat, že již při prrípravě evropské definice terorismu se ze strany některých nevládních organizací vyskytly obavy o údajně možné zneužití některých ustanovení (např. pasáží o vážném zničení veřejného místa nebo soukromého majetku) především proti antiglobalizačním demonstracím a jejich organizátorům (Statewatch 2001). Po přijetí rozhodnutí v Evropském parlamentu 6. února 2002 (484 hlasů pro, 32 proti, 34 poslanců se zdrželo hlasování) uvedl Tony Bunyan z organizace Statewatch: „Evropský parlament nyní podpořil definici terorismu vlád EU - definici, která může být již masivně rozšířena vládami pozdějším rozhodnutím, aniž by byl parlament konzultován. Parlament rovněž souhlasil s vytvořením evropského zatykače, který zásadně postrádá zajištění práv jednotlivce. Tato dvě opatření pouze startují válku svobodě a demokracii“ (Statewatch 2002b). Poukazováno je i na nejasnost toho, co znamená ,vážně poškodit některou zemi nebo mezinárodní organizaci“ (Mareš 2002: 163). Doposud však problémy s aplikací definice, resp. jejím zneužitím, nevznikly.

Na mezistátní úrovni vyvolává problémy zařazení či nezařazení některých organizací na seznamy teroristických osob a organizací, které jsou vypracovávány Radou pro potřeby Společného postoje 2001/931/SZBP a Nařízení rady 2580/2001. V první př́loze ke Společnému postoji Rady z 27. prosince 2001 bylo uvedeno 13 organizací, v poslední aktualizaci do doby napsání tohoto textu ${ }^{23}$ to bylo již 34 organizací. ${ }^{24}$ Je zajímavé, že na seznamu nejsou Al-Kajda ani Taliban. Ty jsou však předmětem zájmu jiných opatření EU. ${ }^{25}$ Bouřlivé diskuse se však vedly nejprve o nezařazení a poté (koncem roku 2003) o zařazení politického kř́dla palestinského hnutí Hamas (jako celek se objevila na seznamu z dubna 2004). Na seznam EU se doposud nedostala šíitská islamistická organizace Hizballáh (průkopník strategie sebevražedných atentátů na Blízkém východě se základnou v Libanonu; je však jako teroristická organizace vedena v obdobných seznamech USA, jež však obecně obsahují mnohem větší množství teroristických subjektů než „,evropský seznam“). EU poukazuje na proklamovanou připravenost libanonské vlády spolupracovat s EU v boji proti terorismu a na legitimitu odporu vůči cizí okupaci (The EU's relations with Lebanon 2003). Na Hizballáh lze podle zvolených úhlů pohlížet jako na teroristickou organizaci i jako na silnou libanonskou politickou stranu s podporou široké libanonské veřejnosti (Kneissl 2002), i když její násilná orientace mj. proti izraelským civilistům je zřejmá. Proto je shovívavý postoj EU k Hizballáhu občas terčem kritiky proamerických a proizraelských sil.

V květnu 2002 se na seznamu objevila i Kurdská strana pracujících (PKK), což vyvolalo protesty velké části kurdského obyvatelstva v zemích EU i mimo ně (spekulovalo se i tom, že se ze strany EU jednalo o ústupek Turecku za to, že nebylo přizváno k rozhovorům o rozšsiřrení EU). Již v dubnu 2002 se přitom na VIII. kongresu PKK rozhodla s ohledem na údajné naplnění „historické mise“ zastavit svoji činnost pod jménem PKK. Současně však byl založen Svobodný a demokratický kongres Kurdistánu (Kongreya Azadi u Demokrasiya Kurdistan - KADEK). Označil se za jediného nástupce PKK a převzal její struktury. Potvrdil i dříve deklarovaný přechod k nenásilné činnosti (Verfassungsschutzbericht 2002), který však zůstává sporný, mj. také s ohledem na vnitřní tlak vůči opozici v kurdském hnutí a vzhledem k existenci ozbrojenců PKK v pohoří Kandil (Manaz 2002). V roce 2003 byl zrušen i KADEK a vznikla nová organizace KONGRA-GEL. 
Proti svému zařazení na seznam se staví i další subjekty. Např. turecká ultralevicová Revoluční lidová osvobozenecká fronta (Devrimici Halk Kurtulus Cephesi - DHKC), která vznikla jako odštěpenecká organizace z Devrimici Sol, ve svém prohlášení k opětovnému zařazení na (z jejího pohledu), ,černou listinu“ EU z 1. listopadu 2002 uvedla, že toto zařazení je důsledkem tlaku USA, především pak CIA na Evropskou unii (což je podle DHKC typické pro celý seznam). Kritizovala, že pro př́pravu listiny v COREPERu neexistuje legislativní oprávnění. Dosavadní účinky „černé listiny“ zhodnotili turečtí levicoví teroristé z DHKC následovně:

a) „Síla USA si podřídila národní vůli členských států EU. Vyvolala situaci, která v policejních organizacích států EU nastolila otázku: Co to má znamenat? Při zhotovení seznamu měly zprávy CIA větší váhu než evropské policejní organizace.

b) V zemích s organizacemi, které byly zařazeny na ,černou listinu“, lze nalézt nejhorší porušování lidských práv. Režimy v zemích, jako jsou Turecko, Izrael, Kolumbie a Peru, jsou známy mučením a masakry obyvatel. Seznam současně znamená, že je vítána a podporována lidem neprrátelská politika těchto zemí. Legitimuje spolupráci s mučiteli.

c) Přestože proti organizacím na seznamu neexistují žádné soudní sankce, byly aktivity těchto organizací na evropské půdě svévolně potlačeny a tím byla uvolněna cesta pro odstranění demokratických práv.

d) Paranoia z teroru, která byla vyvolána na popud USA a s nimi kolaborujících fašistických režimů, se rozšírila po celé Evropě a vyvolala u lidí strach a neklid. Tedy „,̌erná listina" vytvořila atmosféru teroru a jejím prostřednictvím má být dosaženo zvláště terorizování demokratických institucí.

e) ,Černá listina“ vytvořila v Evropě, která je ostatně rodištěm rasismu, základnu pro posílení rasisticko-fašistických sklonů proti Neevropanům obecně.“

(Devrimici Halk Kurtulus Cephesi 2002)

Kromě seznamu osob a skupin zveřejňuje Rada EU od roku 2001 i zprávy (prripravené Europolem) o situaci a trendech terorismu v Evropské unii. Doposud byly zpracovány tři zprávy (za období od záŕí 2000 do září 2001, za období od října 2001 do října 2002 a za období od října 2002 do října 2003). Obsah zpráv byl postupně rozšiřován a byla upřesňována i typologie terorismu. V zatím poslední zprávě lze (po úvodu a shrnutí) nalézt základní rozdělení na a) teroristické aktivity v Evropské unii a b) mezinárodní terorismus (pod tímto názvem je však opět popisována aktivita př́slušných proudů a skupin v zemích EU). Do teroristických aktivit v EU jsou řazeny:

1) separatistický terorismus, a to baskický, severoirský katolický i protestantský a korsický;

2) anarchistická teroristická hnutí (v Řecku, v Itálii a ve Španělsku),

3) zločiny na podporu zvírecích práv a ekoterorismus,

4) bioterorismus,

5) cyberterorismus,

6) levicový terorismus,

7) pravicový terorismus. 
Do mezinárodního terorismu jsou řazeny:

1) islámský extremistický terorismus,

2) turecko-kurdské skupiny,

3) iránské skupiny (resp. pouze Organizace mudžáhidinů lidu Iránu).

K výše uvedené typologii lze podotknout, že dělení na vnitřní a mezinárodní terorismus je s ohledem na základy islamistů na evropském území poněkud problematické. Rovněž zařazení bioterorismu a cyberterorismu je sporné, protože jsou tím v rámci jedné typologie zohledňovány dva faktory - motivace teroristů (separatismus, levicové a pravicové ideologie, náboženství, ochrana životního prostředí a zvířat apod.) a způsob provedení akcí (prostřednictvím biologických zbraní, resp. počítačových sítí). Ostatně i ve zprávě uváděný útok v Belgii se zřejmě vztahoval k islamismu, a proto by bylo vhodnější zařadit jej do části o islámském extremistickém terorismu. Oddělení anarchistického a levicového terorismu nemusí být vždy jednoznačné, navíc napřs. zařazení řecké Revoluční organizace 17. listopadu mezi anarchisty je s ohledem na její marxistickou programatiku sporné (Murray, Ward 1996: 375). Sporné je i oddělení palestinských islamistických skupin jako Al-Tawhid či Brigády mučedníků od Al-Aqsa (které jsou řazeny do blízkovýchodního terorismu) a dalších islamistických skupin, zvláště pak v kontextu současného vytvoření „,konglomerátu“ islamistických extremistů pod zastřešením Al-Kajdy a za pomoci její logistické podpory.

Je zajímavé, že v dosavadních třech situačních zprávách se objevily i organizace, které nefigurují na výše zmíněných seznamech teroristických skupin pro účely Společného postoje 2001/931/SZBP a Nařízení rady 2580/2001. Kromě Al-Kajdy se jedná např. o Continuity IRA, Irish National Liberation Army, Provisional IRA (ta však byla zmiňována pouze v souvislosti s mírovým procesem, nikoliv s konkrétními teroristickými akcemi ve sledovaných obdobích), Ultster Volunteer Force, korsické separatistické skupiny FLNC a Armata Corsa, o anarchistické skupiny Black Block, Gruppe Solidarita Internazionale a Célula Contre al cupital, la Cárcel, los Craceleros y sus Celdas, o militantně „prozvířecí“ Animal Liberation Front, o levicové italské Rudé brigády pro vytvoření bojující komunistické strany, Nuclei Territoriali Antiimperialisti, Centro di Ricera per l'Azione Komunista, Brigata 20 luglio či o berlínskou Militantní skupinu, ultrapravicovou Unité či islamistickou skupinu Al-Tawhid.

I zprávy o situaci terorismu v EU se staly terčem kritiky nevládních organizací. Např. Statewatch odsuzoval zařazení kategorie ekoteroristů a militantních ochránců zvířat s poukazem na omezenost jejich kampaně a údajnou neexistenci definice ekoterorismu, dále upozorňoval na údajně malou pozornost věnovanou ultrapravicovému terorismu (zvláště ve Skandinávii a v Itálii, mj. také s poukazem na teroristy s vazbou na Ordine Nuovo) a především na zařazení ,,anarchistického terorismu“, který je dle Staewatche ve zprávě stavěn „vedle Al-Kajdy“, přičemž není jasné, zda za útoky připisované anarchistům nejsou zodpovědní ultrapravicoví teroristé nebo italská tajná služba SIFAR (Statewatch 2002a). ${ }^{26}$

\section{Závěr}

Soudobá „válka proti terorismu“ (tento pojem je přitom v Evropě na rozdíl od USA často odmítán) probíhá proti „tradičním“ i ,novým“ formám terorismu v různých dimenzích - zpravodajské a policejní, vojenské, finanční a ekonomické (zamezení př́istupu ke zdrojům tero- 
rismu), diplomatické a rozvojové, v oblasti civilní ochrany apod. EU si vytvořila prostřednictvím Europolu základy pro shromažd'ování a výměnu informací. Pro usnadnění výměny slouží i další instituce a organizace, mj. PWGT. Harmonizace trestněprávní legislativy v EU (hmotného i procesního práva) znemožňuje teroristům „legalizovaný“ úkryt v jiné zemi. Opatření proti financování terorismu je samozřejmě třeba realizovat i v rámci EU. Skutečně efektivní by byla jejich aplikace v globálním rámci (např. i v tzv. „daňových rájích“).

Opatření civilní ochrany prováděná v souladu s normami EU jsou důležitá, v př́ípadě masivního teroristického útoku (především ZHN) by samozřejmě velmi záleželo i na osobních schopnostech všech zúčastněných záchranářů a na rychlosti aktivace př́padné mezinárodní spolupráce. V oblasti zahraniční politiky EU nemají konfliktní linie týkající se financování subjektů podezřelých z podpory terorismu či preventivních válek pevně stanovené aktéry a potenciální eskalace střetů v EU (či mezi evropskými státy a USA) vždy závisí na řadě konkrétních okolností. Většina členských zemí EU, jež je současně členy NATO, požaduje komplementární budování struktur obou organizací, které nebude tř́śtit síly v protiteroristické kampani.

\section{Poznámky}

1 Nacistická guerillová organizace Werwolf neměla dlouhého trvání a nedosáhla cílené efektivity. Obdobně dopadly i další nacistické pokusy o restaurační terorismus plánované před pádem Třetí říše.

2 Tento projekt byl zahájen formálním sloučením RAF a AD 15. ledna 1985 (již v roce 1984 se však v okolí RAF objevil časopis Bojovat společně. Časopis antiimperialistické fronty v západní Evropě), nikdy ale nebyl ve větši míře fakticky realizován (ke zvýšení jeho akceschopnosti nevedl ani mezinárodní kongres Antiimperialistický a antikapitalistický odpor v Evropě pořádaný lidmi z okolí RAF, který se konal ve Frankfurtu nad Mohanem ve dnech 31. ledna-4. února 1986). Spolupráce RAF a Rudých brigád nebyla kvůli ideovým rozdílům natolik intenzivní, aby vedla k zamýšlené ,jednotné antiimperialistické frontě“ (větší význam měla spolupráce RAF s menšími italskými skupinami Prima Linea nebo Commando per la Liberazione Proletaria). Teprve v roce 1987 byly navázány užší kontakty s jednou z rozštěpených frakcí RB, a to s Brigatte Rosse - per la Costruzione del Partito Comunisti combattenti. Brzy po utužení kontaktů však byla italská organizace rozbita policií. Společnou aktivitu AD a RAF kritizovaly i španělské ultralevicové organizace Communa Carlos Marx a GRAPO za jejich „radikalismus, spontaneitu a oportunismus“, označily je spíše za „překážku než impulz“ a západoevropskou frontu podle představ RAF a AD označily za ,špatnou parodii“ (Verfassungsschutzbericht 1986: 138-139). GRAPO stabilně kritizovala RAF za malou dogmatičnost a za „chybějícího leninského ducha“" (Peters 1991: 373). Bez větší odezvy zůstaly i snahy o zapojení severoirských teroristů, i když dílčí spolupráce existovala a RAF v lednu 1985 jedno ze svých komand, které 1 . února 1985 zavraždilo průmyslníka Ernesta Zimmermanna, dokonce pojmenovala podle severoirského teroristy Patsy O’Hara (zemřel v květnu 1981 v důsledku hladovky ve vězení v Belfastu; byl př́slušníkem Irish National Liberation Army, což byla malá odštěpenecká skupina z IRA; RAF však mohla jeho jméno zvolit i ,z nouze“, protože nebyl k dispozici žádný „mrtvý mučedník“ z francouzské AD). Stabilněji nebyly (přes dílčí kontakty) do spolupráce zapojeny ani řecká Organizace 17. listopadu a belgické Cellues Communistes Combattantes). Celý projekt „západoevropské guerilly“ v podstatě skončil v souvislosti se zatčením vedení $\mathrm{AD}$ v roce 1987, třebaže dílčí pokusy o jeho obnovení (především ze strany RAF) existovaly i nadále.

V rámci „,antiimperialistické fronty“ byl mj. 10. října 1986 ze strany RAF zavražděn ředitel odboru německého ministerstva zahraničí Gerold von Braunmühl, a to mj. jako výraz nepřátelství RAF vůči sjednocování Evropy, která byla z jejího pohledu nahlížena jako „Čtvrtá říše“ (Rabert 
1995: 135). Braunmühl byl za obět' vybrán též kvůli tomu, že byl zástupcem spolkové vlády v Evropské politické spolupráci (Verfassungsschutzbericht 1986: 130). Ta byla podle RAF „politickou pákou pro prosazení strategicko-politických, ekonomických a vojenských plánů a projektů imperialistické buržoazie v západní Evropě“ a „politickým centrem pro vytvoření evropského pilíře NATO: tam byly v posledních letech určovány linie pro zvýšení politické a vojenské moci západní Evropy, formování západoevropské bezpečnostní politiky, tzn. pro zvyšování agresivního potenciálu evropských států a jejich totální navázání na globální strategii imperialistické buržoazie [...] ES je politická zástěrka, jak dodat mezinárodní váhu západoevropským jaderným státům a jak zakrýt jejich agresi, je nástrojem k propojení státních aparátů a sjednocení politiky západní Evropy v rámci imperialistické ofenzívy proti mezinárodnímu proletariátu“ (Rote Armee Fraktion 1986). Útoky proti EU však přicházely i z jiných ultralevicových organizací bez vazby na výše zmíněný projekt RAF a AD.

Např. atentátem italských neofašistů na nádraží Bologni v roce 1980 s 81 obět’mi anebo útokem německého neonacisty na pivních slavnostech v Mnichově v témže roce s 13 obět’mi (Hoffmann 1993).

$4 \quad$ Naopak se v základních smlouvách vyskytovaly spíše normy, které zdůrazňovaly suverenitu členských zemí v oblasti vnitřní bezpečnosti. Členským zemím bylo např. podle čl. 36 smlouvy o EHS dovoleno, aby si i v podmínkách vnitřního trhu zachovaly omezení, která by bránila dovozu, vývozu nebo tranzitu takového zboží, které by ohrožovalo zemi z hlediska veřejné mravnosti, veřejného pořádku, veřejné bezpečnosti. Podobné omezení platilo i pro vstup a tranzit osob (čl. 48 Smlouvy o EHS). S ohledem na další spolupráci však byla ve Smlouvě o EHS zmíněna možnost zahájení jednání mezi členskými státy ve věci ochrany osob a jejich práv a dále jednání ve prospěch zjednodušení formalit při výkonu soudních rozhodnutí a rozhodčích výroků (Fiala, Pitrová 2003: 594).

5 Interpol např. po tragédii na olympijských hrách v Mnichově, kde palestinské komando Černé září uneslo izraelské sportovce a následně je zabilo $\mathrm{v}$ přestřelce $\mathrm{s}$ německou policií na letišti, odmítl participovat na vyšetřování s poukazem na údajný politický charakter činu. I později se bránil př́lišné angažovanosti v problematice terorismu, mj. také z obavy před reakcí členských arabských zemí. Změna v př́stupu Interpolu k terorismu nastala až v osmdesátých letech (Bresler 1994: 136-191). Kromě neochoty Interpolu zabývat se terorismem byla v sedmdesátých letech ze strany západoevropských policistů kritizována i špatná ochrana dat a pomalost a těžkopádnost postupů $\mathrm{v}$ jeho rámci (Knelangen 2001: 89).

6 Podle většiny interpretací se jedná o zkratku slov „terrorism“, „radicalism“, „extremism“, „,violence international“" Jiní autoři však tvrdí, že je to pouze reinterpretace, protože původní název souvisí s římskou fontánou Trevi. Označení údajně při pohledu na tuto památku navrhl tehdejší nizozemský ministr vnitra Fontein (v překladu „fontána“) (Bresler 1994: 145; Misilegas, Monar, Rees 2003: 23).

7 V rámci pracovní skupiny TREVI I byla realizována následující témata:

a) analýza ohrožení od terorismu a její stálá aktualizace,

b) výměna informací o situaci,

c) výměna informací o cizincích z třetích zemí představujících ohrožení,

d) výměna informací o krádežích výbušnin a zbraní teroristů,

e) zřízení chráněných telexových a telekopiových spojení,

f) opatření $\mathrm{k}$ usnadnění pátrání po teroristech,

g) vytvoření centrálních koordinačních struktur v boji proti terorismu,

h) Srovnání a iniciování právních základů pro policejní vyšetřování financování teroristických aktivit.

V každém státě byla zřízena spojovací kancelář (např. při národních kriminálních policejních ústř̌ednách) s chráněným komunikačním systémem. Výměna informací nebyla právně nijak specificky upravena. Probíhala na základě bilaterálních smluv a ještě více na neformální úrovni (Knelagen 2001: 93). 
Mezivládní spolupráce v oblasti třetího pilíře se v kontextu protiteroristické politiky stala rovněž terčem kritiky, a to v tom smyslu, že nad natolik citlivou oblastí liberální demokracie neexistuje důkladnější soudní a parlamentní kontrola Evropského parlamentu a Evropského soudního dvora (Chalk 2000: 203).

9 Schengenský systém spočívá především na dvou základních dohodách. První schengenská dohoda o postupném odstraňování kontrol na společných hranicích některých států Společenství byla sjednána 14. června 1985 s tím, že nevyžadovala ratifikaci a prováděla se na prozatímním základě. K jejímu provedení byla v červnu 1990 sjednána prováděcí dohoda (Schengenská prováděcí úmluva), která již vyžadovala ratifikaci parlamenty států smluvních stran Schengenu. V platnost vstoupila 26. března 1995. Jejími členy je nyní třináct členských států EU (členy nejsou Velká Británie a Irsko), přidruženými zeměmi jsou Norsko a Island. Podstatou schengenské spolupráce bylo vytvoření zóny volného pohybu se zrušením kontrol na společných hranicích (tzv. schengenský prostor) za paralelního přijetí série mechanismů a konkrétních opatření sledujících udržení a současně i zvyšování úrovně veřejné bezpečnosti v členských státech. Přijatá opatření měla současně ztížit možnost zneužívání svobody pohybu ke kriminálním aktivitám (tj. i teroristům). Schengenská prováděcí úmluva zakotvuje zejména otázky překračování vnitřních a vnějších hranic a navazující problematiku vízovou, dále policejní spolupráci, právní pomoc ve věcech trestních a ustanovení o fungování tzv. schengenského informačního systému, včetně ochrany osobních údajů. Záběr schengenské spolupráce zahrnuje mnohem širší oblast než pouze protiteroristickou politiku, představuje však její důležitou součást. Objevují se však i obavy, aby neoprávněně šířený strach z „kriminality“ a „terorismu“ přistěhovalců nevedl k potlačování jejich lidských práv (Crelinsten, Özkut 2000).

10 Od ratifikace Maastrichtské smlouvy do ratifikace Amsterodamské smlouvy byly nástroji třetího pilíře:

a) společný postoj (měl být obhajován členskými státy v rámci mezinárodních organizací a konferencí a byl přijímán jednomyslně Radou),

b) společná akce (byla přijímána jednomyslně, avšak nebyla ve smlouvě přesně definována),

c) úmluvy.

Kromě úmluv jakožto nástrojů mezinárodního práva veřejného byl právní status těchto nástrojů sporný.

11 Úkolem národní jednotky je:

a) poskytovat Europolu z vlastního podnětu informace a poznatky potřebné pro plnění jeho úkolů;

b) odpovídat na žádosti Europolu o informace, poznatky a konzultace;

c) aktualizovat informace a poznatky;

d) v souladu s vnitrostátními právními předpisy vyhodnocovat informace a poznatky pro př́slušné orgány a poskytovat jim je;

e) obracet se na Europol s žádostmi o konzultace, informace, poznatky a analýzy;

f) poskytovat Europolu informace k ukládání údajů do počítačových systémů zpracování;

g) zajistit soulad s právními předpisy při každé výměně informací mezi ní a Europolem.

Národní jednotka není povinna poskytnout informace a poznatky, pokud by to poškodilo podstatné národní zájmy nebo ohrozilo úspěch probíhajícího vyšetřování nebo bezpečnost jednotlivce nebo se to týkalo informací pocházejících ze zpravodajských služeb nebo zvláštních zpravodajských činností týkajících se vnitřní bezpečnosti (Pikna 2003: 236-237).

12 Již od počátku spadaly do př́slušnosti Europolu nedovolený obchod s drogami, obchod s jadernými a radioaktivními látkami, převaděčství, obchod s lidmi, trestná činnost týkající se motorových vozidel a posléze (od května 1998) i spáchané trestné činy (nebo ty, které by mohly být spáchány) $\mathrm{v}$ rámci teroristických činů proti životu, zdraví a osobní svobodě nebo proti majetku. Př́íslušnost Europolu rovněž zahrnovala nedovolené praní špinavých peněz spojené s těmito formami činnosti a s tím související trestné činy. Rada v prosinci 2001 s účinností od 1. ledna 2002 rozšiříila mandát 
Europolu o další závažné formy mezinárodní kriminality, uvedené v př́loze k Úmluvě o Europolu. Jedná se o trestnou činnost proti životu, zdraví a osobní svobodě (vražda, těžká újma na zdraví, nedovolený obchod s lidskými orgány a tkáněmi, únos, omezování osobní svobody a braní rukojmí, rasismus a xenofobie), proti majetku včetně majetku veřejného a včetně podvodu (organizovaná loupež, nedovolený obchod s kulturními statky, včetně starožitností a uměleckých děl, podvodná jednání, vydírání a vymáhání peněz za ochranu, výroba padělků a nedovolených napodobenin, padělání veřejných listin a obchodování s nimi, padělání peněz a platebních prostředků, počítačová trestná činnost, korupce) a nedovolený obchod a trestné činy proti životnímu prostředí (nedovolený obchod se zbraněmi, střelivem a výbušninami, nedovolený obchod s ohroženými druhy živočichů, nedovolený obchod s ohroženými druhy a odrůdami rostlin, trestné činy proti životnímu prostředí a nedovolený obchod s hormonálními látkami a jinými prostředky na podporu růstu). I u těchto forem trestné činnosti se Europol začal zabývat praním peněz a souvisejícími trestnými činy (Úmluva založená na článku K.3 Smlouvy o Evropské unii a zrrízení Evropského policejního úřadu [Úmluva o Europolu 1995]). V roce 2002 se Rada rozhodla, že Europol se bude zabývat jakýmkoliv praním špinavých peněz (aby nevznikly problémy při určování toho, zda se jedná o praní špinavých peněz z výše uvedených činností).

13 Např. německá strana Spojenectví 90/Zelení v roce 1998 uvedla: „Úmluva o Europolu nesmí být ratifikována. Jsou jí podkopávány ochrana dat, občanská práva a státní rozdělení moci (parlamentní a soudní kontrola nad exekutivou). Europol je klasický byrokratický recept proti kriminalitě a nepřispívá k potírání jejích příčin“ (Bündnis 90/Die Grünen 1998).

Př́istup nového členského státu je možný pouze po přizvání $\mathrm{k}$ účasti schváleném dvoutřetinovou většinou dosavadních členů. Členy jsou i dvě nečlenské země EU, a sice Norsko a Švýcarsko.

Již od 1. března 2001 fungovala jako provizorní tzv. předběžná jednotka pro soudní spolupráci pod označením Pro-Eurojust.

16 Společné vyšetřovací týmy byly zakotveny již v Amsterodamské smlouvě a později upraveny několika dokumenty EU, především pak v článku 13 Úmluvy o vzájemné pomoci ve věcech trestních mezi členskými státy Evropské unie z 29. května 2000. V ní se uvádí: „Př̌́slušné orgány dvou nebo více členských států mohou na základě vzájemné dohody zř́ídit společný vyšetřovací tým pro určitý účel a na určitou dobu, která může být prodloužena, s cílem vést trestní vyšetřování v jednom nebo více členských státech, které tým zř́ídily. Složení týmu se stanoví v dohodě.

Společný vyšetřovací tým se zřizuje zejména $\mathrm{v}$ těchto př́ípadech:

a) vyšetřování trestných činů prováděné členským státem vyžaduje obtížné a náročné vyšetřování, které souvisí s jinými členskými státy;

b) několik členských států provádí vyšetřování trestných činů, přičemž okolnosti př́ípadu vyžadují koordinovaný postup provedený ve vzájemné shodě členských států, kterých se postup týká“ (Pikna 2003: 252).

Např. v únoru 2004 zveřejnil německý týdeník Die Welt informace, které převzala i další média, o tom, že podle tajné zprávy OLAF skončily desítky milionů dolarů z humanitární pomoci EU palestinské samosprávě na účtech teroristických organizací Fatáh-Tanzim a Hamás (Artuz Sheva 2004).

Podle některých představ (např. švédského poslance Görana Lenmarkera) by ochranu vnějších hranic EU zajišt'oval národní policejní sbor př́slušného členského státu a evropský celek by fungoval propojením relevantních národních centrál.

V dlouhodobé perspektivě definovalo vytvoření EIA mj. Parlamentní shromáždění Západoevropské unie v roce 2002 (Recommendation 707 on the new challenges facing European intelligence - reply to annual report of the Council 2002).

Amsterodamská smlouva upřesnila nástroje vymezené v Maastrichtské smlouvě, navíc zavedla i společné strategie. 
V současnosti však stále platí modifikovaná Bruselská smlouva z roku 1954, jejíž článek V. obsahuje ustanovení o kolektivní sebeobraně členských států. Snahu o přesunutí modifikované Bruselské smlouvy do EU zatím neutrální státy odmítají (Had, Pikna 2001: 56). Evropský parlament navrhl úplně zrušit ZEU v roce 2004. Někteří plnoprávní členové ZEU se však obávají, že by s jejím definitivním zánikem a ukončením platnosti článku $\mathrm{V}$. ztratily bezpečnostní status, který jim společná bezpečnostní a obranná politika EU nenahradí (Algieri 2002: 180).

EU již v průběhu devadesátých let vypracovala řadu dokumentů využitelných v boji proti mezinárodnímu terorismu (at' již zaměřených výhradně na oblast terorismu, nebo se širším bezpečnostně-politickým záběrem). Již výše byla zmíněna Úmluva o zřízení Evropského policejního úřadu - Europolu - z roku 1995. Další relevantní úmluvy jsou Úmluva o zjednodušeném extradičním řízení mezi členskými státy Evropské unie z roku 1995 a Úmluva o extradici mezi členskými státy Evropské unie z roku 1996. Terorismu se věnovaly i dvě deklarace Rady EU, a to Deklarace o financování terorismu ze 30. listopadu 1993 a Deklarace o terorismu ze dne 14. ř́ijna 1995, dále pak tzv. Společná akce týkající se vytvoření a udržování Seznamu specializovaných protiteroristických schopností, znalostí a zkušeností k usnadnění protiteroristické spolupráce mezi členskými státy Evropské unie a Doporučení Rady EU o spolupráci v boji s financováním teroristických skupin z 9. prosince 1999 aj. Evropská unie se terorismem zabývala i v kontextu některých opatření SZBP, která měla za cíl zamezit vzniku nebo nárůstu terorismu v krizových oblastech (např. Společná akce k programu EU na podporu úřadů palestinské autonomie při jejich snahách potírat teroristické aktivity, které vycházejí z území pod jejich kontrolou). Ve druhé polovině devadesátých let se k problematice terorismu začala na svých zasedáních pravidelně vyslovovat Evropská rada (Madrid 1995, Tampere 1999, Santa Maria da Feira 2000). V roce 1996 proběhlo v Evropském parlamentu slyšení na téma boje proti terorismu, které zorganizoval výbor EP pro osobní svobody a vnitřní záležitosti (Šturma, Nováková, Bílková 2003: 49-50).

23 V době psaní tohoto textu byla zatím poslední aktualizace provedena Radou 12. zááí 2003 Společným postojem (2003/651/SZBP), který aktualizuje Společný postoj 2001/931SZBP o specifických opatřeních v boji proti terorismu a nahrazuje Společný postoj 2003/482/SZBP a Rozhodnutím Rady (2003/646/ES) zaměřeným na implementaci specifických restriktivních opatření podle Nařizení (ES) č. 2580/2001 proti určitým osobám a subjektům, a nahrazení Rozhodnutí 2003/480/ES.

Konkrétně se jedná o skupiny a seskupení (názvy jsou uvedeny v anglickém přepisu):

1) Abu Nidal Organisation (a.k.a. Fatah Revolutionary Council, Arab Revolutionary Brigades, Black September, Revolutionary Organisation of Socialist and Muslims),

2) Al-Aqsa Martyr's Brigade,

3) Al-Takfir a Al-Hirja,

4) Aum Shinrikyo (a.k.a. AUM, Aum Supreme Truth, a.k.a. Aleph),

5) Babbar Khalsa,

6) Continuity Irish Republican Army,

7) Euskadi Ta Askatasuna/Sierra Vasca y Libertad/Basque Fatherland and Liberty (E.T.A.) (včetně jejích částí K.a.s., Xaki, Ekin, Jarrai-Haika-Segi, Gestoras pro amnistía, Askatasuna, Batasuna (a.k.a. Herri Batasuna, a.k.a. Euskal Herritarrok),

8) Gama'a al-Islamyya (Islamic Group) (a.k.a. Al-Gama'a al-Islamyya, IG),

9) Grupos de Resistencia Antifascista Primero de Octubre/Antifascist Resistence Groups First of October (G.R.A.P.O.),

10) Hamas (včetně Hamas-Izz-al-Din al Quassem),

11) Holy Land Foundation for Relief and Development,

12) International Sikh Youth Federation,

13) Kahane Chai (Khah), 
14) Kurdistan Workers' Party (a.k.a. PKK),

15) Laskhar e Tayyaba (a.k.a. LET)/Pashan-e-Ahle Hadis,

16) Loyalist Volunter Force (LFV),

17) Mujahedin-e Lhala Organisation (MEK or MKO) (minus the „National Council of Resistence of Iran“ [NCRI], a.k.a. The National Liberation Army of Iran [NLA, militantní křídlo MEK], the People's Mujahidin of Iran [PMOI] a Muslim Iranian Student's Society),

18) New Peoples Army (NPA), Philippines, linked to Sison Jose Maria C. (a.k.a. Armando Liwanag, a.k.a. Joma, in charge of NPA),

19) Orange Volunteers,

20) Palestine Liberation Front,

21) Palestinian Islamic Jihad,

22) Popular Front for the Liberation of Palestine,

23) Popular Front for the Liberation of Palestine-General Command (a.k.a. PFLP - General Command, a.k.a. PFPL-GC),

24) Real IRA,

25) Red Hand Defenders,

26) Revolutionary Armed Forces in Colombia (a.k.a. FARC),

27) Revolutionary Nuclei/Epanastatiki Pirines,

28) Revolutionary Organisation 17. November/Dekati Evdomi Noemvri,

29) Revolutionary People's Liberation Army/Front Party (DHKP/C) (a.k.a. Devrimici Sol [Revolutionary Left], Dev Sol),

30) Revolutionary Popular Struggle/Epanastatikos Laikos Agonas,

31) Shining Path,

32) Stitching Al-Sasa (a.k.a. Stitching Al-Aqsa Nederland, a.k.a. Al-Aqsa Nederland),

33) Ulster Defence Association/Ulster Freedom Fighters,

34) United Self-Defence Forces/Group of Columbia (AUC) (Autodefensas Unidas de Colombia).

Po 11. září 2001 se jednalo především o Společný postoj Rady 2002/402/SZBP z 27. května 2002 o restriktivních opatřeních proti Usámovi bin Ládinovi, členům organizací Al-Kajda a Talibanu a dalším s nimi spjatým jednotlivcům, skupinám, podnikům a seskupením, nahrazující Společné postoje 96/746/SZBP, 1999/727/SZBP, 2001/154/SZBP a 2001/771/SZBP a Nařízení Rady (ES) č. 881/2002 z 27. května 2002 ukládající určitá zvláštní restriktivní opatření proti určitým osobám a seskupením spojeným s Usámou bin Ládinem, sítí Al-Kajda a Talibanem a nahrazujícím nařízení Rady (ES) č. 467/2001.

26 Úvahy o údajném zinscenování alespoň části anarchistického terorismu se v levicových kruzích opětovně objevily poté, co byly pod hlavičkou Federazione Anarchica Informale (FAI) koncem roku 2003 rozeslány dopisní bomby různým osobám a institucím v EU (mj. předsedovi Evropské komise Romanu Prodimu, Eurojustu, Europolu, Evropské centrální bance a předsedovi Evropské lidové strany). Italská anarchistická federace (Federazione Anarchica Italiana - FAI, tj. organizace se stejnou zkratkou jako má výše zmíněná skupina) označila neformální anarchistickou federaci za „fantom“ a uvedla, že ten, ,kdo užívá takové iniciály a vystavuje „skupinu soudruhů/soudružek represi, je agent nebo kolaborant policie““(Federazione Anarchica Italiana 2003).

\section{Bibliografie}

Prameny

Úřední dokumenty a legislativa Evropských společenství a Evropské unie

A Secure Europe in a better world. 2003.

Amsterodamská smlouva. 1997. Ministerstvo zahraničních věcí České republiky, Praha. 
„Nařízení Rady (ES) č. 2580/2001 o zvláštních restriktivních opatřeních namířených proti určitým osobám a subjektům s cílem bojovat proti terorismu“". 2001. In Pikna, B.: Evropská unie - vnitřní a vnějši bezpečnost a ochrana základních práv (na pozadí boje proti mezinárodnímu terorismu). Praha: Linde, s. 427-435.

Plenární setkání Konventu 6.-7. 6. 2002.2002 [online] [cit. 13. 9. 2002]. Dostupné z: http://www.euroskop.cz

Rámcové rozhodnutí Rady z 13. června 2002 o boji proti terorismu 2002/475/JHA. 2002.

Recommendation 707 on the new challenges facing European intelligence - reply to annual report of the Council. 2002. Assembly of WEU.

Rozhodnutí Rady (2003/646/ES) zaměřené na implementaci specifických restriktivních opatření podle Nařízení (ES) č. 2580/2001 proti určitým osobám a subjektům, a o nahrazení Rozhodnutí 2003/480/ES. 2003.

Situace v oblasti teroristických aktivit v Evropské unii. Aktuální stav a tendence. 2002.

Společný postoj Rady z 27. prosince 2001 o boji proti terorismu. 2003.

Společný postoj (2003/651/SZBP) aktualizující společný postoj 2001/931SZBP o specifických opatřeních v boji proti terorismu a nahrazující Společný postoj 2003/482/SZBP. 2003.

The EU's relations with Libanon. 2003 [online] [cit. 16. 2. 2004]. Dostupné z: http://europa.eu.int/comm/external_relations/lebanon/intro

Úmluva založená na článku K.3 Smlouvy o Evropské unii a zrŕzení Evropského policejního úřadu (Úmluva o Europolu). 1995.

Usnesení a akční plán mimořádného zasedání Evropské rady z 21. září 2001. 2001 [online] [cit. 14. 7. 2003]. Dostupné z http://www.mvcr.cz

Veřejná zpráva o situaci a tendencích terorismu Evropě. 2002.

Veřejná zpráva o teroristických aktivitách v Evropské unii od ř́ijna 2002 do říina 2003. 2003.

\section{Ostatní prameny}

Artuz Sheva. 2004. Secret EU Findings. European Donations To P. A. Were Used For Terrorism. Dostupné z http://www.artuzsehva.com [cit.16. 2. 2004].

Česká tisková kancelář. 1990. „Výbory FS, branné a bezpečnostní“, 6. září 1990.

Česká tisková kancelár. 2001. „Vláda odsoudila víkendové teroristické útoky palestinských organizací proti Izraeli“", 3. prosince 2001.

Česká tisková kancelář. 2003. „Europoslance zajímaly u ČR dekrety a otázky spjaté s Irákem“, 11. února 2003.

Čulík, J. 2004. „O italských politických atentátnících v komunistickém Československu“, Britské listy, 19. února 2004. Dostupné z http://www.blisty.cz/2004/2/19/ art17050.html

Devrimici Halk Kurtulus Cephesi. 2002. Die EU setzt ihre Demagogie im Bezug auf die „Schwarze Liste“ fort [online] [cit. 16. 2. 2004]. Dostupné z: http://www.dhkc.net/de/ article.php?sid=115

Federazione Anarchica Italiana. 2003. Pressemitteilung der FAI. Graswurzel Revolution, 33. Jg., Nr. 286, s. 2.

Marek, J. 2001. „Podporoval komunistický režim terorismus?“ Český rozhlas, 2. října 2001. Dostupné z http://www.radio.cz/cz/clanek/4327 [cit. 16. 2. 2004].

Menschlik, T., Blechová, S. 2003. „Premiér Špidla se střetl se Chirakem. Český předseda vlády na summitu EU prosadil tvrdou linii vůči Hamasu“. Lidové noviny, 26. 6. 2003, s. 1. 
Rote Armee Fraktion. 1986. Anschlag auf Gerold von Braunmühl. Erklärung der RAF vom 10. Oktober 1986. Dostupné z: http:/www.extremismus.com/terror/rafdox19.html [cit. 16. 2. 2004].

Statewatch. 2001. EU to adopt new laws on terrorism. Dostupné z: http://www.statewatch.org/ news/2001/sep/14eulaws.htm [cit. 19. 1. 2004].

Statewatch. 2002a. EU definition of Terrorism: Anarchist to be targeted as ,terrorist “ along alongside Al Qaeda. Statewatch Analysis No. 10.

Statewatch. 2002b. European Parliament supports EU definition of terrorism and European arrest warrant. Dostupné z: http://www.statewatch.org/news/2002/news/2002/feb/ 06ep.html [cit. 19. 1. 2004].

Verfassungsschutzbericht 1986. 1987. Bonn: Bundesminister des Inneren.

Verfassungsschutzbericht 2002. 2003. Hamburg: Behörde für Inneres.

Odborná literatura

Algieri, F. 2001. „Die Europäische Sicherheits- und Verteidigungspolitik: erweiterer Handlungsspielraum für die GASP“. In Weidenfeld, W. (Hrsg.) Nizza in der Analyse. Strategien für Europa. Gütersloh: Verlag Bertelsmann Stiftung, s. 161-201.

Bonanate, L. 1997. Mezinárodní terorismus. Praha: Columbus.

Bresler, F. 1994. Interpol. Vimperk, Rudná u Prahy: Papyrus, Jeva.

Brzybohatý, M. 1999. Terorismus II. Praha: Police History.

Bündnis 90/Die Grünen. 1998. Europol - Wunderwaffe gegen Kriminalität? Europol-Symbol ohne Sicherheitsgewinn. Dostupné z: http://www.gruene-fraktion.de [cit. 3. 12. 1998].

Carr, C. 2002. Dějiny terorismu. Kořeny války proti civilistům. Praha: Práh.

Crelinsten, Ronald, Özkut, Iffet. 2000. „Counterrorism Policy in Fortress Europe. Implications for Human Rights“. In Reinares, F. (ed.) European Democracies Against Terrorism. Governmental Policies And Intergovernmental Cooperation. Dartmouth: Asghate, s. 245-271.

Delpech, T. 2002. International terrorism and Europe. Paris: Institute for Security Studies.

Dietl, W. 1995. Carlos. Konec jednoho mýtu. Vimperk: Tina.

Fiala, P., Pitrová, M. 2003. Evropská unie. Brno: Centrum pro studium demokracie a kultury.

Former, F., Formerová, L. 2003. „Integrovaný záchranný systém“. Security Magazín, roč. X, č. 54 , s. 5-18.

Had, M., Pikna, B. 2001. Druhý a třetí pilǐr Evropské unie. Praha: Ústav mezinárodních vztahů.

Hoffmann, B. 1993. „Right-Wing Terrorism in Europe“. In Moxon-Browne, E. (ed.) European Terrorism. Aldershot: Dartmouth Publishing, s. 16-26.

Hoffmann, B. 2001. Terrorismus. Der unerklärte Krieg. Neue Gefahren politischer Gewalt. Frankfurt am Main: Fischer.

Hubáčková, H. 2000. „Evropská bezpečnostní a obranná politika. Průběžné hodnocení ze strany české diplomacie: stav po druhé třetině“. In Khol, R. (ed.) Česká republika a Evropská bezpečnostní a obranná politika. Praha: Ústav mezinárodních vztahů, s. 9-14.

Janošec, J. 2003. „Terorismus a Armáda České republiky“. Obrana a strategie, roč. 3, č. 2, s. 61-76.

Chalk, P. 2000. „The Third Pillar on Judical and Home Affairs Cooperation, Anti-terrorist Collaboration and Liberal Democratic Acceptability“. In Reinares, Fernando (ed.) European Democracies Against Terrorism. Governmental policies and intergovernmental cooperation. Dartmouth: Asghate, s. 175-210.

Kamp, K. H. 2004. Vorbeugende Militäreinsätze (Preemtive Strikes). Sankt Augustin: Konrad Adenauer Stiftung. 
Karlas, J. 2004. „OBSE a boj s terorismem: důsledky pro její roli““. Mezinárodní politika, roč. XXVIII, č. 1, s. 18-20.

Khol, R. 2001. „Mezinárodní terorismus a Evropská unie“. Bezpečnostní témata, roč. 1, č. 1, S. $9-10$.

Khol, R. 2002. „Nové bezpečnostní prostředí po 11. září a Evropská unie - Dopad na Českou republiku“. In Nové bezpečnostni prostředí po 11. záři a Evropská unie. Praha: Friedrich Ebert Stiftung, Ústav mezinárodních vztahů, s. 21-23.

Khol, R. 2003a. „Bezpečnostní strategie Evropské unie“. Bezpečnostni témata, roč. 3, č. 2, s. 7-8.

Khol, R. (ed.) 2003b. Evropská bezpečnostní a obranná politika. Národní perspektivy. Praha: Ústav mezinárodních vztahů.

Kohout, J. 2002. „Vliv nového bezpečnostního prostředí po útocích na USA na bezpečnostní dimenzi EU a její rozšiřování - dopad na Českou republiku jako kandidátskou zemi“. In Nové bezpečnostni prostředi po 11. záři a Evropská unie. Praha: Friedrich Ebert Stiftung, Ústav mezinárodních vztahů, s. 25-27.

Knelangen, W. 2001. Das Politikfeld innere Sicherheit im Integrationsprozess. Die Entstehung einer europäischen Politik der inneren Sicherheit. Opladen: Leske + Budich.

Kneissl, K. 2002. Hizbollah: Libanesische Widerstandsbewegung, islamische Terrorgruppe oder bloss eine politische Partei? Eine Untersuchung der schiitischen Massenbewegung Hizbollah im libanesischen und regionalen Kontext. Wien: Landesverteidigungsakademie.

Krulík, O. 2002. Terorismus a organizovaný zločin ve střední a východní Evropě. Brno: Ústav strategických studií Vojenské akademie v Brně.

Krulík, O. 2003. Česká republika v boji proti terorismu. Brno: Ústav strategických studií Vojenské akademie v Brně.

Křepelka, F. 2002. „EUROPOL jako policie nadnárodního celku“. In Dančák, B., Šimíček, V. (eds.) Bezpečnost České republiky. Právní aspekty situace po 11. září 2001. Brno: Masarykova univerzita, s. 214-222.

Langguth, G. 1993. „Origins and Aims of Terrorism in Europe“. In Moxon-Browne, E. (ed.) European Terrorism. Aldershot: Dartmouth Publishing, s. 163-175.

Manaz, A. 2002. PKK - KADEK'S Past and Today. Dostupné z: http://www.teror.gen.tr/ english/news/a_manaz_eng.html [cit. 4. 11.2003].

Mareš, M. 2002b. „Problém právní definice terorismu“. In Dančák, B., Šimíček, V. (eds.) Bezpečnost České republiky. Právní aspekty situace po 11. záři 2001. Brno: Masarykova univerzita v Brně, s. 162-168.

Marotta, E. 2001. „Europol's Role in Anti-Terrorism Policing““. In Taylor, M., Horgan, J. (eds.) The Future of Terrorism. London, Portland: Frank Cass, s. 15-18.

Mitsilegas, V., Monar, J., Rees, W. 2003. The European Union and Internal Security. Guardian of the People? New York: Palgrave MacMillan.

Müller, H. 2003. Terrorism, proliferation: an European threat assessment. Paris: Institute for Security Studies.

Murray, J., Ward, R. H. 1996. Extremist Groups. An International Compilation of Terrorist Organisations, Violent Political Groups, and Issue-Oriented Militantn Movements. Chicago: Office of International Criminal Justice. The University of Illions at Chicago.

Musil, J. 2001. „Polizei- und Strafrechtszusammenarbeit - Vorbereitungen und Perspektiven in der Tschechischen Republik“. In Merli, F. (Hrsg.) Der Raum der Freiheit, der Sicherheit und des Rechts und die Osterweiterung der Europäischen Union. Dresden: Thelem, s. 95-109. 
Novotný, J. 2000. „Evropská bezpečnostní a obranná politika a Česká republika. Průběžné hodnocení ze strany české diplomacie: stav po druhé třetině“. In Khol, R. (ed.) Česká republika a Evropská bezpečnostní a obranná politika. Praha: Ústav mezinárodních vztahů, s. $15-20$.

Nožina, M. 2003. Mezinárodní organizovaný zločin v České republice. Praha: Themis.

Olshausen, K. 2004. „Bericht aus Brüssel“. Soldat und Technik, 47 Jahrgang, Nr. 2, s. 56-57.

Peters, B. 1991. RAF. Terrorismus in Deutschland. Stuttgart: Deutsche Verlags-Anstalt.

Pikna, B. 2002. Evropská unie - vnitřní a vnějši bezpečnost a ochrana základních práv (na pozadí boje proti mezinárodnímu terorismu). Praha: Linde.

Pikna, B. 2003. Vnitřní bezpečnost a veřejný pořádek v evropském právu (oblast policejní a justiční spolupráce). Praha: Linde.

Rabert, B. 1995. Links- und Rechtsterrorismus in der Bundesrepublik Deutschland von 1970 bis heute. Bonn: Bernard \& Graefe Verlag.

Strmiska, M. 2001. Terorismus a demokracie. Pojetí a typologie subverzívního teroristického násilí v soudobých demokraciích. Brno: Masarykova univerzita v Brně.

Šedivý, J. 2002. „Obecná proměna strategického prostředí po 11. zář́i 2001“. In Nové bezpečnostní prostředí po 11. záři a Evropská unie. Praha: Friedrich Ebert Stiftung, Ústav mezinárodních vztahů, s. 5-10.

Šturma, P., Nováková, J., Bílková, V. 2003. Mezinárodní a evropské instrumenty proti terorismu a organizovanému zločinu. Praha: C. H. Beck.

Tůma, M. 2002. Neširené zbraní hromadného ničení, kontrola zbrojení, odzbrojení a Česká republika. Praha: Ústav mezinárodních vztahů.

Zariski, R. 1989. „Ethnic Extremism among Ethnoteritorial Minorities in Western Europe. Dimensions, Causes, and Institutional Responses“. Comparative Politics, Vol. 21, No. 3, s. $253-272$.

\section{Autor}

JUDr. PhDr. Miroslav Mareš, Ph.D. (1974) působí jako odborný asistent na katedře politologie FSS MU. V letech 2003-2004 pobýval jako hostující vyučující studia politologie na Filozofické fakultě Technické univerzity v Chemnitz. Specializuje se na problematiku výzkumu extremismu a terorismu a na teorii politických stran (především v politických systémech České republiky a Evropské unie). Autor či editor řady odborných textů a publikací, mj. Pravicový extremismus a radikalismus v ČR (2003). Kontakt: mmares@fss.muni.cz 